\title{
Magnetic and luminescent coordination networks based on imidazolium salts and lanthanides for sensitive ratiometric thermometry
}

\author{
Pierre Farger ${ }^{1}$ § , Cédric Leuvrey ${ }^{1}$, Mathieu Gallart ${ }^{1}$, Pierre Gilliot ${ }^{1}$, Guillaume Rogez ${ }^{1}$, \\ João Rocha ${ }^{2}$, Duarte Ananias ${ }^{2}$, Pierre Rabu*1 and Emilie Delahaye ${ }^{* 1}$
}

\section{Full Research Paper}

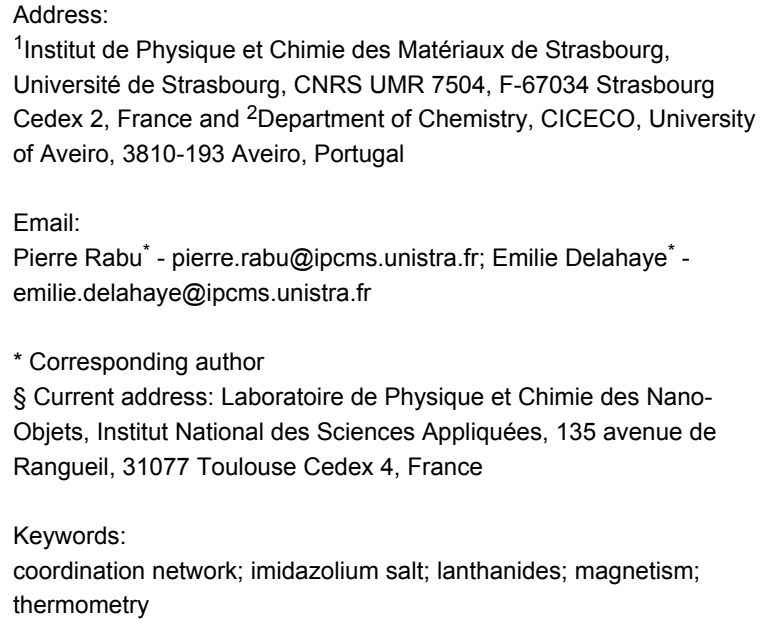

${ }^{1}$ Institut de Physique et Chimie des Matériaux de Strasbourg, Université de Strasbourg, CNRS UMR 7504, F-67034 Strasbourg Cedex 2, France and ${ }^{2}$ Department of Chemistry, CICECO, University of Aveiro, 3810-193 Aveiro, Portugal

Email:

Pierre Rabu* - pierre.rabu@ipcms.unistra.fr; Emilie Delahaye* emilie.delahaye@ipcms.unistra.fr

* Corresponding author

$\S$ Current address: Laboratoire de Physique et Chimie des NanoObjets, Institut National des Sciences Appliquées, 135 avenue de Rangueil, 31077 Toulouse Cedex 4, France

Keywords:

coordination network; imidazolium salt; lanthanides; magnetism; thermometry

Beilstein J. Nanotechnol. 2018, 9, 2775-2787. doi:10.3762/bjnano.9.259

Received: 15 August 2018

Accepted: 11 October 2018

Published: 30 October 2018

This article is part of the thematic issue "Advanced hybrid nanomaterials". Associate Editor: S. A. Claridge

(c) 2018 Farger et al.; licensee Beilstein-Institut. License and terms: see end of document.

\begin{abstract}
The synthesis and characterization of six new lanthanide networks $\left[\mathrm{Ln}(\mathrm{L})(\mathrm{ox})\left(\mathrm{H}_{2} \mathrm{O}\right)\right]$ with $\mathrm{Ln}=\mathrm{Eu}^{3+}, \mathrm{Gd}^{3+}, \mathrm{Tb}^{3+}, \mathrm{Dy}^{3+}, \mathrm{Ho}^{3+}$ and $\mathrm{Yb}^{3+}$ is reported. They were synthesized by solvo-ionothermal reaction of lanthanide nitrate $\mathrm{Ln}\left(\mathrm{NO}_{3}\right)_{3} \cdot x \mathrm{H}_{2} \mathrm{O}$ with the 1,3bis(carboxymethyl)imidazolium [HL] ligand and oxalic acid $\left(\mathrm{H}_{2} \mathrm{Ox}\right)$ in a water/ethanol solution. The crystal structure of these compounds has been solved on single crystals and the magnetic and luminescent properties have been investigated relying on intrinsic properties of the lanthanide ions. The synthetic strategy has been extended to mixed lanthanide networks leading to four isostructural networks of formula $\left[\mathrm{Tb}_{1-x} \mathrm{Eu}_{x}(\mathrm{~L})(\mathrm{ox})\left(\mathrm{H}_{2} \mathrm{O}\right)\right]$ with $x=0.01,0.03,0.05$ and 0.10 . These materials were assessed as luminescent ratiometric thermometers based on the emission intensities of ligand, $\mathrm{Tb}^{3+}$ and $\mathrm{Eu}^{3+}$. The best sensitivities were obtained using the ratio between the emission intensities of $\mathrm{Eu}^{3+}\left({ }^{5} \mathrm{D}_{0} \rightarrow{ }^{7} \mathrm{~F}_{2}\right.$ transition $)$ and of the ligand as the thermometric parameter. $\left[\mathrm{Tb}_{0.97} \mathrm{Eu}_{0.03}(\mathrm{~L})(\mathrm{ox})\left(\mathrm{H}_{2} \mathrm{O}\right)\right]$ was found to be one of the best thermometers among lanthanide-bearing coordination polymers and metal-organic frameworks, operative in the physiological range with a maximum sensitivity of $1.38 \% \cdot \mathrm{K}^{-1}$ at $340 \mathrm{~K}$.
\end{abstract}

\section{Introduction}

Metal-organic coordination networks have been the subject of considerable research in the last years as evidenced by the increasing number of papers published in the field [1]. Indeed, the possibility of combining different properties by judicious choice of the organic and inorganic moieties makes these systems good candidates for the elaboration of (multi)functional architectures 
$[2,3]$. Among the various functionalities that can be envisioned for this class of hybrid compounds, the elaboration of luminescent networks is interesting in term of potential applications in lighting, display, sensing, biomedicine and for optical devices [4-12].

Luminescent coordination networks can be obtained either by the use of specific luminescent organic ligands or by the use of main-group elements, $\mathrm{d}^{10}$ transition metals or of trivalent lanthanide ions for the inorganic moiety $[13,14]$. The luminescent properties of the trivalent lanthanide ions are particularly interesting since they cover a large range of emission from the ultraviolet $\left(\mathrm{Gd}^{3+}\right)$ to near-infrared $\left(\mathrm{Pr}^{3+}, \mathrm{Nd}^{3+}, \mathrm{Ho}^{3+}, \mathrm{Er}^{3+}\right.$, $\left.\mathrm{Yb}^{3+}\right)$ through the visible domain $\left(\mathrm{Pr}^{3+}, \mathrm{Sm}^{3+}, \mathrm{Eu}^{3+}, \mathrm{Tb}^{3+}\right.$, $\left.\mathrm{Dy}^{3+}, \mathrm{Tm}^{3+}\right)$. It confers to lanthanide-based networks a large tunability of emission properties, which is very useful for the elaboration of light-emitting devices or for biomedical applications [15]. Moreover, due to the narrowness and the hypersensitivity of their transitions, lanthanide-based networks can also find utility for the sensing of gases, vapors or small molecules $[9,16]$. In the case of mixed lanthanide coordination networks, the luminescent properties can be used to synthesize temperature probes with possible applications in the aerospace area, safety and health $[17,18]$.

Beside luminescent properties, lanthanide ions exhibit large magnetic moment and strong magnetic anisotropy, which might have potential applications of lanthanide-based networks in information storage, quantum computing and spintronics [1923].

Most of these lanthanide-based networks are obtained with neutral organic ligands such as benzene-1,4-dicarboxylate $(1,4-$ bdc) [24], benzene-1,3,5-tricarboxylate (TMA) [25], pyridine2,5-dicarboxylate $\left(2,5-\mathrm{H}_{2} \mathrm{pdc}\right)$ [24] or 1H-2-propyl-4,5-imidazoledicarboxylate (pimda) [26]. Only few examples of lanthanide-based networks obtained with charged ligands are reported in the literature [27-30]. Following this last point, we have chosen to synthesize lanthanide-based networks from positively charged imidazolium dicarboxylate salts [31-34]. Contrarily to the classical imidazolium salts or ionic liquids used in ionothermal syntheses [35-40], the functionalization of imidazolium moieties with coordinating functions reduces the influence of the imidazolium salt on the ligand for a better rationalization of the synthesis [31-34].

We report in this paper the synthesis and the characterization of six new networks obtained from an imidazolium dicarboxylate salt, oxalic acid and lanthanide ions. The structure of these networks has been solved by single crystal X-ray diffraction and their physical properties (magnetism and luminescence) have been investigated. We establish that these networks show antiferromagnetic interactions. The study of the luminescent properties evidences the presence of well-defined transitions characteristic for the considered lanthanide. These results have prompted us to extend our strategy to the synthesis of mixed lanthanide networks with four different ratios $\mathrm{Tb}^{3+} / \mathrm{Eu}^{3+}$. The powder X-ray diffraction analysis indicates that these mixed lanthanide networks are isostructural to the parent homolanthanide compounds. The temperature-resolved photo-luminescent properties of the latter indicate possible applications in thermometry.

\section{Results and Discussion Synthesis}

The 1,3-bis(carboxymethyl-)-imidazolium ligand [HL] was synthesized according to protocols published in the literature $[41,42]$.

Single crystals and homogeneous powders of $\left[\mathrm{Ln}(\mathrm{L})(\mathrm{ox})\left(\mathrm{H}_{2} \mathrm{O}\right)\right]$ were obtained with $\mathrm{Ln}=\mathrm{Eu}^{3+}, \mathrm{Gd}^{3+}, \mathrm{Tb}^{3+}, \mathrm{Dy}^{3+}, \mathrm{Ho}^{3+}$ and $\mathrm{Yb}^{3+}$ by reacting a water/ethanol solution of the lanthanide nitrate and oxalic acid $\left(\mathrm{H}_{2} \mathrm{Ox}\right)$ with [HL]. The mixture was sealed in a Teflon-lined stainless steel autoclave and heated at $393 \mathrm{~K}$ for $72 \mathrm{~h}$. After cooling to room temperature, the autoclaves were opened and crystals were filtered and washed with ethanol. The yields of the reactions range from 36 to $59 \%$. Similar reactions were carried out with $\mathrm{Nd}^{3+}$ and $\mathrm{Sm}^{3+}$ ions leading to different structures [31]. In addition, in the case of $\mathrm{Nd}^{3+}$ and $\mathrm{Sm}^{3+}$, various crystalline compounds were obtained depending on whether oxalic acid was added or not. When oxalic acid was not added in situ formation of the oxalate ligand has been observed. The peculiar behavior of these two ions compared to others can be explained by their place in the first part of the lanthanide series [43]. In the case of $\mathrm{Eu}^{3+}, \mathrm{Gd}^{3+}, \mathrm{Tb}^{3+}, \mathrm{Dy}^{3+}$, $\mathrm{Ho}^{3+}$ and $\mathrm{Yb}^{3+}$, described in the present work, the direct reaction between lanthanide nitrate and [HL], without addition of oxalic acid, did not give crystalline compounds.

\section{Characterization of the homolanthanide $\left[\mathrm{Ln}(\mathrm{L})(\mathrm{ox})\left(\mathrm{H}_{2} \mathrm{O}\right)\right]$ compounds with $\mathrm{Ln}=\mathrm{Eu}^{3+}$, $\mathrm{Gd}^{3+}, \mathrm{Tb}^{3+}, \mathrm{Dy}^{3+}, \mathrm{Ho}^{3+}$ and $\mathrm{Yb}^{3+}$}

Single crystal X-ray analysis of the $\left[\mathrm{Ln}(\mathrm{L})(\mathrm{ox})\left(\mathrm{H}_{2} \mathrm{O}\right)\right]$ compounds with $\mathrm{Ln}=\mathrm{Eu}^{3+}, \mathrm{Gd}^{3+}, \mathrm{Tb}^{3+}, \mathrm{Dy}^{3+}, \mathrm{Ho}^{3+}$ and $\mathrm{Yb}^{3+}$ reveal that the six compounds are isostructural. All compounds are obtained as colorless crystals and crystallize in the monoclinic space group $P 2{ }_{1} / a$ (no. 14). Crystal data for these series of compounds are collected in Table 1 and Table 2.

The asymmetric unit contains one $\mathrm{Ln}^{3+}$ ion, one $[\mathrm{L}]^{-}$ligand, two half-oxalate ligands and one coordinating water molecule (Figure 1). $\mathrm{Ln}^{3+}$ ions are surrounded by nine oxygens with four 


\begin{tabular}{|c|c|c|c|}
\hline & {$\left[\mathrm{Eu}(\mathrm{L})(\mathrm{ox})\left(\mathrm{H}_{2} \mathrm{O}\right)\right]$} & {$\left[\mathrm{Gd}(\mathrm{L})(\mathrm{ox})\left(\mathrm{H}_{2} \mathrm{O}\right)\right]$} & {$\left[\mathrm{Tb}(\mathrm{L})(\mathrm{ox})\left(\mathrm{H}_{2} \mathrm{O}\right)\right]$} \\
\hline chemical formula & $\mathrm{C}_{9} \mathrm{H}_{9} \mathrm{~N}_{2} \mathrm{O}_{9} \mathrm{Eu}$ & $\mathrm{C}_{9} \mathrm{H}_{9} \mathrm{~N}_{2} \mathrm{O}_{9} \mathrm{Gd}$ & $\mathrm{C}_{9} \mathrm{H}_{9} \mathrm{~N}_{2} \mathrm{O}_{9} \mathrm{~Tb}$ \\
\hline molar mass $\left[\mathrm{g} \cdot \mathrm{mol}^{-1}\right]$ & 441.14 & 446.43 & 448.10 \\
\hline crystal system & monoclinic & monoclinic & monoclinic \\
\hline space group & $P 2_{1} / a$ & $P 2_{1} / a$ & $P 2_{1} / a$ \\
\hline$a[\AA]$ & $9.212(3)$ & $9.224(4)$ & $9.246(3)$ \\
\hline$b[\AA]$ & $13.228(4)$ & $13.226(4)$ & $13.219(9)$ \\
\hline$c[\AA]]$ & $10.9893(17)$ & $10.950(2)$ & $10.904(3)$ \\
\hline$\alpha\left[^{\circ}\right]$ & 90 & 90 & 90 \\
\hline$\beta\left[^{\circ}\right]$ & $111.491(18)$ & $111.48(2)$ & $111.63(2)$ \\
\hline $\mathrm{V}\left[{ }^{\circ}\right]$ & 90 & 90 & 90 \\
\hline$Z$ & 4 & 4 & 4 \\
\hline$T[\mathrm{~K}]$ & $293(2)$ & $293(2)$ & $293(2)$ \\
\hline$\mu(\mathrm{Mo} \mathrm{K \alpha})\left[\mathrm{mm}^{-1}\right]$ & 5.044 & 5.366 & 5.716 \\
\hline reflection collected & 11538 & 6602 & 14582 \\
\hline independent reflections & 2854 & 2825 & 2840 \\
\hline data/restraints/parameters & $2854 / 3 / 196$ & $2825 / 3 / 196$ & $2840 / 3 / 196$ \\
\hline $\mathrm{R} 1, \mathrm{wR} 2[I>2 \sigma(I)]$ & $0.0358,0.0690$ & $0.0268,0.0458$ & $0.0427,0.0769$ \\
\hline R1, wR2 [all data] & $0.0579,0.0770$ & $0.0430,0.0501$ & $0.0627,0.0850$ \\
\hline GOOF & 1.063 & 1.092 & 1.094 \\
\hline largest diff. peak and hole $\left(e \cdot \AA^{-3}\right)$ & $1.297,-1.365$ & $0.681,-0.689$ & $1.868,-1.838$ \\
\hline
\end{tabular}

aThe relatively high values of the residual density can be explained by the difficulty to isolate single crystals. Indeed SEM images reveal the presence of relatively small and entangled crystals (see Figure S3, Supporting Information File 1).

Table 2: Crystallographic data for $\left[\mathrm{Ln}(\mathrm{L})(\mathrm{ox})\left(\mathrm{H}_{2} \mathrm{O}\right)\right]$ compounds with $\mathrm{Ln}=\mathrm{Dy}^{3+}, \mathrm{Ho}^{3+}$ and $\mathrm{Yb}^{3+}$.

\begin{tabular}{|c|c|c|c|}
\hline & {$\left[\mathrm{Dy}(\mathrm{L})(\mathrm{ox})\left(\mathrm{H}_{2} \mathrm{O}\right)\right]$} & {$\left[\mathrm{Ho}(\mathrm{L})(\mathrm{ox})\left(\mathrm{H}_{2} \mathrm{O}\right)\right]$} & {$\left[\mathrm{Yb}(\mathrm{L})(\mathrm{ox})\left(\mathrm{H}_{2} \mathrm{O}\right)\right]$} \\
\hline chemical formula & $\mathrm{C}_{9} \mathrm{H}_{9} \mathrm{~N}_{2} \mathrm{O}_{9} \mathrm{Dy}$ & $\mathrm{C}_{9} \mathrm{H}_{9} \mathrm{~N}_{2} \mathrm{O}_{9} \mathrm{Ho}$ & $\mathrm{C}_{9} \mathrm{H}_{9} \mathrm{~N}_{2} \mathrm{O}_{9} \mathrm{Yb}$ \\
\hline molar mass $\left[\mathrm{g} \cdot \mathrm{mol}^{-1}\right]$ & 451.68 & 454.11 & 462.22 \\
\hline crystal system & monoclinic & monoclinic & monoclinic \\
\hline space group & $P 2_{1} / a$ & $P 2_{1} / a$ & $P 2_{1} / a$ \\
\hline$a[\AA]$ & $9.191(4)$ & $9.228(10)$ & $9.193(2)$ \\
\hline$b[\AA]$ & $13.188(4)$ & $13.185(4)$ & $13.097(3)$ \\
\hline$c[\AA]$ & $10.85(5)$ & $10.862(8)$ & $10.721(5)$ \\
\hline$\alpha\left[^{\circ}\right]$ & 90 & 90 & 90 \\
\hline$\beta\left[^{\circ}\right]$ & $111.63(3)$ & 111.95(6) & $112.19(3)$ \\
\hline $\mathrm{V}\left[{ }^{\circ}\right]$ & 90 & 90 & 90 \\
\hline Z & 4 & 4 & 4 \\
\hline$T[\mathrm{~K}]$ & $293(2)$ & 293(2) & $293(2)$ \\
\hline$\mu(\mathrm{Mo} \mathrm{Ka})\left[\mathrm{mm}^{-1}\right]$ & 6.137 & 6.479 & 7.843 \\
\hline reflection collected & 13140 & 13992 & 7321 \\
\hline independent reflections & 2802 & 2814 & 2735 \\
\hline data/restraints/parameters & $2802 / 3 / 196$ & $2814 / 3 / 196$ & 2735/3/196 \\
\hline $\mathrm{R} 1, \mathrm{wR} 2[I>2 \sigma(I)]$ & $0.0336,0.0573$ & $0.0494,0.0751$ & $0.0516,0.1119$ \\
\hline R1, wR2 [all data] & $0.0517,0.0624$ & $0.0854,0.0840$ & $0.0914,0.1319$ \\
\hline GOOF & 1.122 & 1.133 & 1.031 \\
\hline largest diff. peak and hole $\left(e \cdot \AA^{-3}\right)$ & $0.742,-1.382$ & $1.164,-1.034$ & $2.751,-2.662$ \\
\hline
\end{tabular}

aThe relatively high values of the residual density can be explained by the difficulty to isolate single crystals. Indeed SEM images reveal the presence of relatively small and entangled crystals (see Figure S3, Supporting Information File 1). 


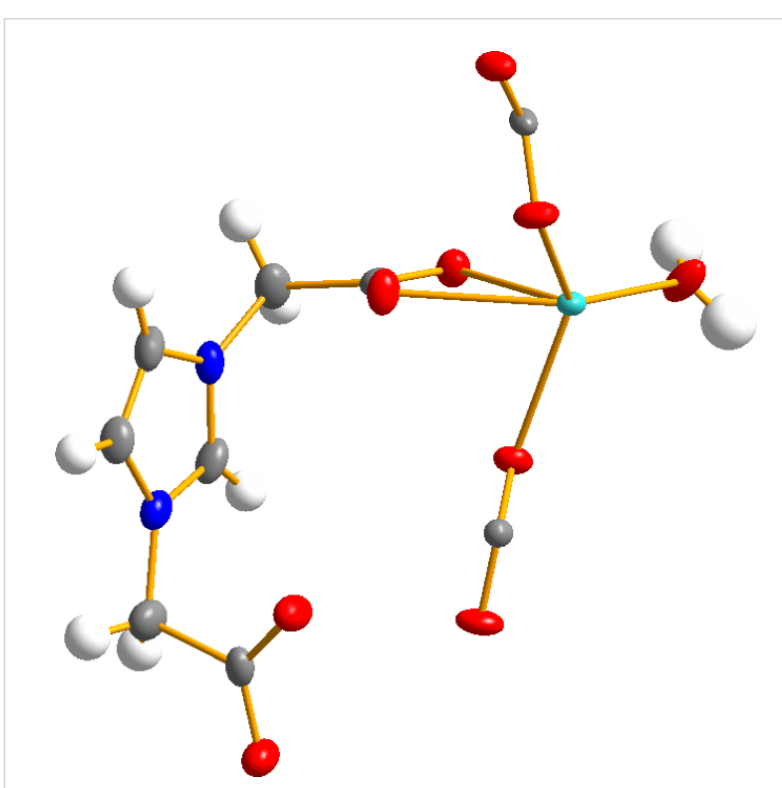

Figure 1: Ellipsoid view of the asymmetric unit of $\left[\mathrm{Gd}(\mathrm{L})(\mathrm{ox})\left(\mathrm{H}_{2} \mathrm{O}\right)\right](\mathrm{Gd}$ in green, $\mathrm{C}$ in grey, $\mathrm{O}$ in red, $\mathrm{N}$ in blue and $\mathrm{H}$ in white).

oxygen atoms coming from one and same carboxylate function of two different $[\mathrm{L}]^{-}$ligands, one from the water molecule and four from two different oxalate ligands. The coordination environment of $\mathrm{Ln}^{3+}$ ions is a tricapped trigonal prism (Figure $\mathrm{S} 1$, Supporting Information File 1) with $\mathrm{Ln}-\mathrm{O}$ distances similar to those observed in structurally related compounds [44,45]. These distances decrease progressively with the size of the lanthanide ion in agreement with the lanthanide contraction effect (Table S1, Supporting Information File 1). The same tendency is observed with the shortest $\mathrm{Ln}-\mathrm{Ln}$ distances, which correspond to two $\mathrm{Ln}^{3+}$ ions connected by an oxalate ligand (Table S1, Supporting Information File 1).

Two separate $\mathrm{Ln}^{3+}$ ions are connected through an oxalate ligand in a bis-bidentate bridging coordination mode forming undulating chains along the $a$-axis (Figure 2). The $\mathrm{Ln}^{3+}$ ions are connected to the carboxylate functions of the $[\mathrm{L}]^{-}$ligand in a bidentate chelate mode. The cohesion between these chains is realized through $\mathrm{H}$ bonding between $\mathrm{H}$ atoms of the coordinated water molecules and $\mathrm{O}$ atoms of the carboxylate functions.

Beside the single crystal analysis, the homogeneity of the six samples was checked by powder X-ray diffraction. As shown in Figure S2 (Supporting Information File 1), the experimental powder patterns fit well with the patterns calculated from the single crystal structure and show no additional phases.

In order to investigate the thermal stability, thermogravimetric analysis (TGA) was realized under air stream from 25 to $900{ }^{\circ} \mathrm{C}$ (Figure S4, Supporting Information File 1). The weight loss

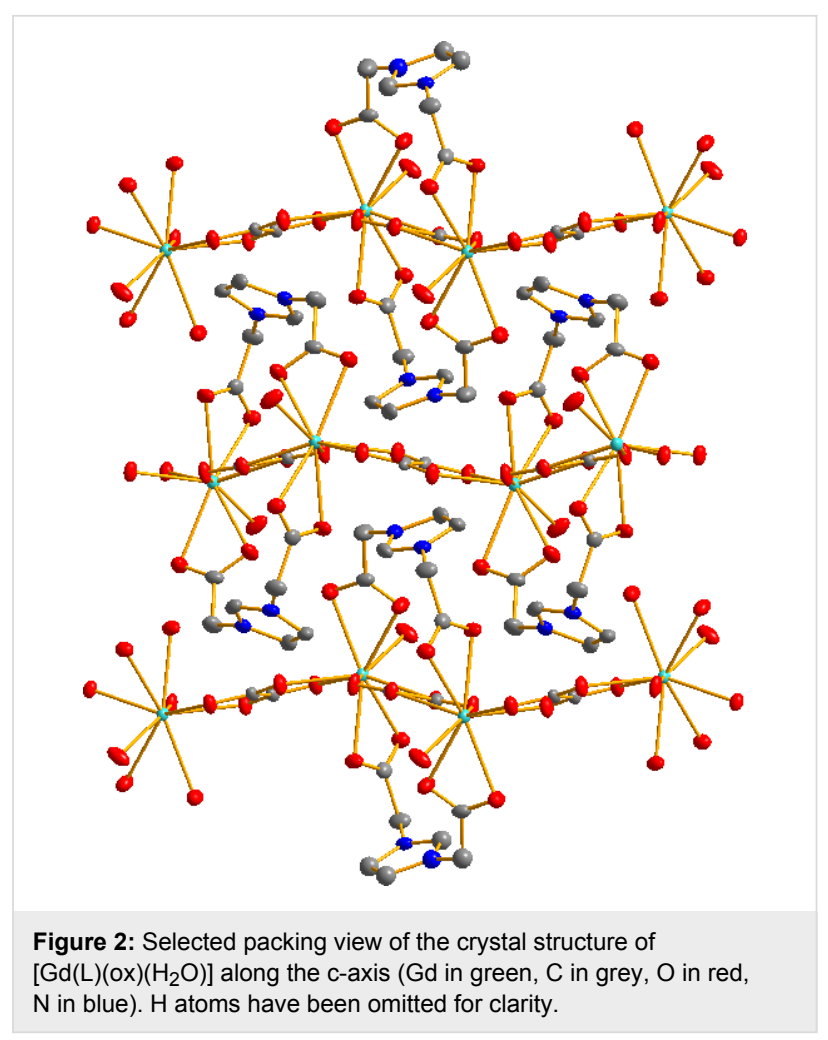

corresponding to the elimination of the coordinated water molecule occurs between 130 and $310{ }^{\circ} \mathrm{C}$ (step 1). The second weight loss between 310 and $750{ }^{\circ} \mathrm{C}$ (step 2) is associated to the combustion of the organic moieties (oxalate and $[\mathrm{L}]^{-}$ligands), concomitant with the formation of oxide $\left(\mathrm{Ln}_{2} \mathrm{O}_{3}\right.$ was identified by powder X-ray diffraction in the final product). The total weight loss is in good agreement with the calculated values (Table S2, Supporting Information File 1).

The infrared spectra of the six compounds are similar (Figure S5, Supporting Information File 1). The broad band around $3250 \mathrm{~cm}^{-1}$ and the one at $1672 \mathrm{~cm}^{-1}$ are ascribed to the coordinated water (stretching and bending vibration modes, respectively). The vibration bands of the aromatic and aliphatic $\mathrm{C}-\mathrm{H}$ bonds are observed in the range $3150-3050 \mathrm{~cm}^{-1}$ and $3050-2950 \mathrm{~cm}^{-1}$, respectively. The characteristic frequencies of the coordinating carboxylate functions are observed at 1627 and $1571 \mathrm{~cm}^{-1}$ (antisymmetric vibration bands) and at 1411 and $1431 \mathrm{~cm}^{-1}$ (symmetric vibration bands). It leads to $\Delta v$ $\left(\Delta v=v_{\text {antisym }}-v_{\text {sym }}\right)$ equal to 216 and $140 \mathrm{~cm}^{-1}$ in agreement with a bis-bidentate bridging coordination mode of the oxalate ligand and a bidentate chelate coordination mode of the carboxylate functions of the $[\mathrm{L}]^{-}$ligand, respectively $[46,47]$.

\section{Magnetic properties}

The magnetic behavior of the six compounds $\left[\mathrm{Ln}(\mathrm{L})(\mathrm{ox})\left(\mathrm{H}_{2} \mathrm{O}\right)\right]$ have been studied in the temperature range of $1.8-300 \mathrm{~K}$ under 
a $0.5 \mathrm{~T}$ dc magnetic field. The magnetic susceptibilities and products $\chi T$ are presented as functions of the temperature in Figure 3 .

At $300 \mathrm{~K}$, the value of $\chi T$ for the compound $\left[\mathrm{Gd}(\mathrm{L})(\mathrm{ox})\left(\mathrm{H}_{2} \mathrm{O}\right)\right]$ is $7.88 \mathrm{emu} \cdot \mathrm{K} \cdot \mathrm{mol}^{-1}$, which agrees well with the theoretical value for spin-only $S=7 / 2 \mathrm{Gd}^{3+}$ ions. The $\chi T$ product remains almost constant above $30 \mathrm{~K}$ and then decreases down to $6.7 \mathrm{emu} \cdot \mathrm{K} \cdot \mathrm{mol}^{-1}$ at $1.8 \mathrm{~K}$. This decrease suggests the occurrence of antiferromagnetic coupling between neighboring gadolinium centers. Since $\left[\mathrm{Gd}(\mathrm{L})(\mathrm{ox})\left(\mathrm{H}_{2} \mathrm{O}\right)\right]$ is constituted of linear chains of $\mathrm{Gd}^{3+}$ ions with large spin moment, $S=7 / 2$, we evaluated the magnetic coupling, $J$, between neighboring $\mathrm{Gd}^{3+}$ ions by using the Fisher expression for classical spin chains $[48,49]$ :

$$
\chi=\frac{N g^{2} \beta^{2} S(S+1)}{3 k T} \cdot \frac{1+\operatorname{coth}\left[\frac{J S(S+1)}{k T}\right]-\frac{k T}{J S(S+1)}}{1-\operatorname{coth}\left[\frac{J S(S+1)}{k T}\right]-\frac{k T}{J S(S+1)}} .
$$

In the above expression, $N$ is the Avogadro number, $g$ is the Landé factor, $\beta$ is the Bohr magneton, $k$ is the Boltzmann constant, $S$ is the spin moment, $J$ is the magnetic coupling constant and $T$ is the temperature. The simultaneous fitting of the suscep- tibility and the $\chi T$ product with the Fischer expression above lead to refined values of $g=2.00(1)$ and $J=-0.026 \mathrm{~cm}^{-1}$. The $g$ value was left free during fitting and is in line with the tabulated $g$ values for $\mathrm{Gd}$ ions [50]. The absolute value and the sign of $J$ support the presence of weak antiferromagnetic interactions in $\left[\mathrm{Gd}(\mathrm{L})(\mathrm{ox})\left(\mathrm{H}_{2} \mathrm{O}\right)\right]$, in agreement with results reported in previous works [51-53]. The magnetic exchange coupling between lanthanide ions is usually weak, due to limited extension of the $4 \mathrm{f}$ orbitals.

For $\left[\mathrm{Eu}(\mathrm{L})(\mathrm{ox})\left(\mathrm{H}_{2} \mathrm{O}\right)\right]$, the $\chi T$ product decreases continuously from $1.4 \mathrm{emu} \cdot \mathrm{K} \cdot \mathrm{mol}^{-1}$ at $300 \mathrm{~K}$ to $0 \mathrm{emu} \cdot \mathrm{K} \cdot \mathrm{mol}^{-1}$ at $1.8 \mathrm{~K}$. This behavior is typical for $\mathrm{Eu}^{3+}$ ions for which the ${ }^{7} \mathrm{~F}$ ground term is split in seven ${ }^{7} \mathrm{~F}_{J}(0 \leq J \leq 6)$ states because of spin-orbit coupling $[54,55]$. The spin-orbit coupling constant, $\lambda$, can be evaluated considering isotropic isolated $\mathrm{Eu}^{3+}$ ions parametrized with the appropriate expression (E1 in Supporting Information File 1) for the isotropic susceptibility of $\mathrm{Eu}^{3+}$ ions [54,55].

A very good fit of the experimental susceptibility and the $\chi T$ product of $\left[\mathrm{Eu}(\mathrm{L})(\mathrm{ox})\left(\mathrm{H}_{2} \mathrm{O}\right)\right]$ was obtained above $25 \mathrm{~K}$ giving the refined value of $\lambda=309.00(4) \mathrm{cm}^{-1}$. This value is consistent with the value determined from the luminescence measurements (see below) and confirms that considering only the isotropic component of the susceptibility is a good approximation to analyze the magnetic data [54].
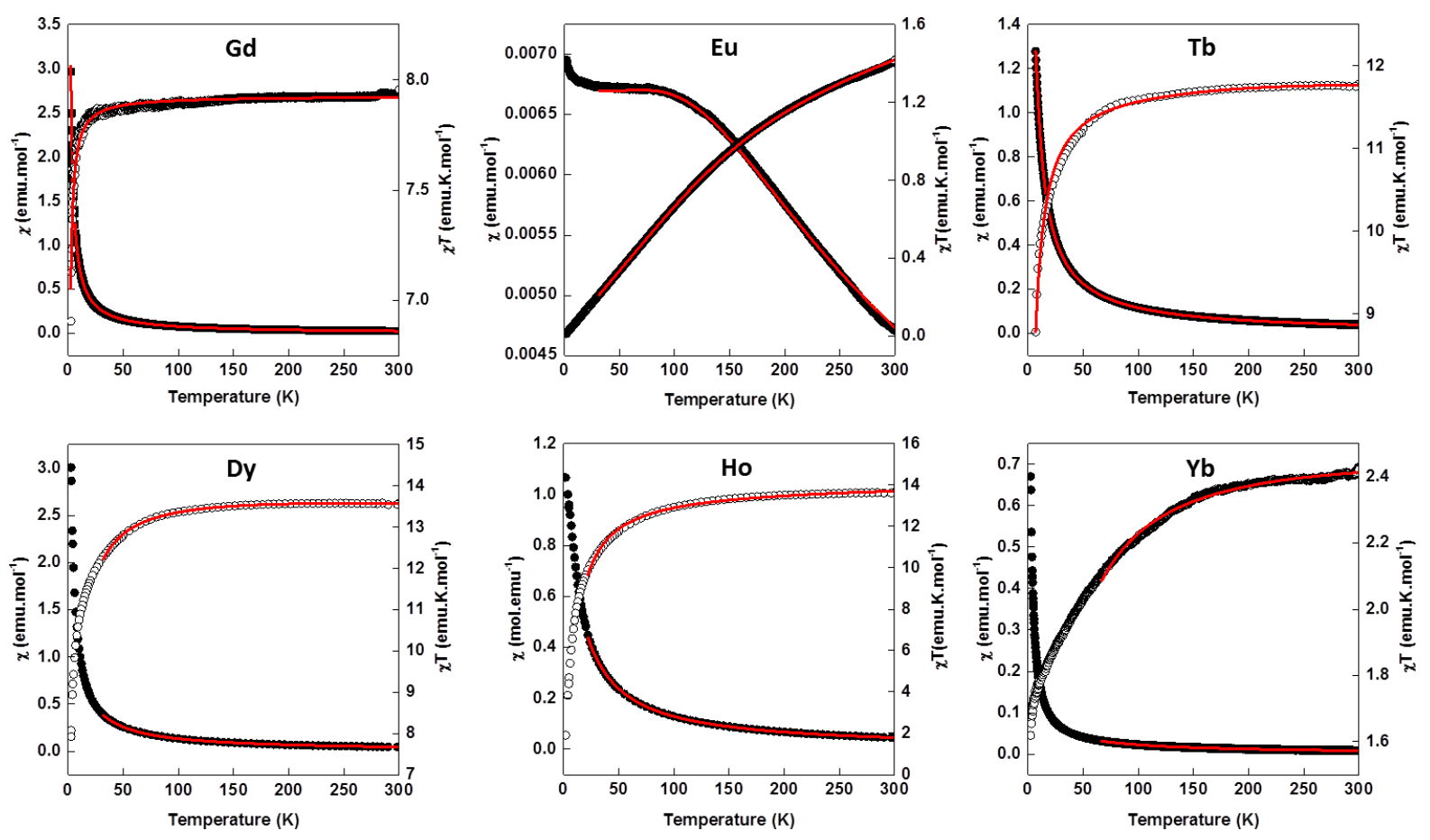

Figure 3: Plots of $X$ (closed circles) and $X T$ (open circles) as functions of $T$ for $\left[\mathrm{Ln}(\mathrm{L})_{2}(\mathrm{ox})\left(\mathrm{H}_{2} \mathrm{O}\right)\right]$ with $\mathrm{Ln}=\mathrm{Gd}^{3+}, \mathrm{Eu}^{3+}, \mathrm{Tb}^{3+}, \mathrm{Dy}^{3+}, \mathrm{Ho}^{3+}$ and $\mathrm{Yb}^{3+}$ The full lines correspond to the fit of the data using the expressions discussed in the text and given in Supporting Information File 1. 
The behavior of $\left[\mathrm{Tb}(\mathrm{L})(\mathrm{ox})\left(\mathrm{H}_{2} \mathrm{O}\right)\right]$ is also typical for quasi-isolated $\mathrm{Tb}^{3+}$ ions with $\chi T=11.75 \mathrm{emu} \cdot \mathrm{K} \cdot \mathrm{mol}^{-1}$ at $300 \mathrm{~K}(\mathrm{ex}-$ pected value: $11.82 \mathrm{emu} \cdot \mathrm{K} \cdot \mathrm{mol}^{-1}$ with $\left.g=1.5\right)[48,50]$. When decreasing the temperature, the $\chi T$ product remains constant until $100 \mathrm{~K}$ and then decreases to $4.50 \mathrm{emu} \cdot \mathrm{K} \cdot \mathrm{mol}^{-1}$ at $1.8 \mathrm{~K}$. This decay is due to the depopulation of the low-lying $J$ states arising from the splitting of the ${ }^{7} \mathrm{~F}$ ground term under spin-orbit coupling. In order to determine the spin-orbit coupling, $\lambda$, it was necessary to take into account an antiferromagnetic interaction between neighboring $\mathrm{Tb}^{3+}$ ions using a mean-field approach, in addition to the intrinsic behavior of isolated $\mathrm{Tb}^{3+}$ ions (E5 in Supporting Information File 1) [56].

Subsequently, a good fit of the magnetic data was obtained on the whole temperature range with $\lambda=-303(75) \mathrm{cm}^{-1}$ and $z J^{\prime}=-0.106(1) \mathrm{cm}^{-1}$. The obtained $\lambda$ value is consistent with other values reported in the literature for compounds containing isolated $\mathrm{Tb}^{3+}$ ions $[57,58]$.

In the case of $\left[\mathrm{Dy}(\mathrm{L})(\mathrm{ox})\left(\mathrm{H}_{2} \mathrm{O}\right)\right],\left[\mathrm{Ho}(\mathrm{L})(\mathrm{ox})\left(\mathrm{H}_{2} \mathrm{O}\right)\right]$ and $\left[\mathrm{Yb}(\mathrm{L})(\mathrm{ox})\left(\mathrm{H}_{2} \mathrm{O}\right)\right]$ the $\chi T$ values at $300 \mathrm{~K}$ are $13.82,13.61$ and $2.48 \mathrm{emu} \cdot \mathrm{K} \cdot \mathrm{mol}^{-1}$, in line with the theoretical values for isolated $\mathrm{Dy}^{3+}$ ions $\left(14.17 \mathrm{emu} \cdot \mathrm{K} \cdot \mathrm{mol}^{-1}\right.$ with $\left.g=1.33\right)[50] \mathrm{Ho}^{3+}$ ions $\left(14.07 \mathrm{emu} \cdot \mathrm{K} \cdot \mathrm{mol}^{-1}\right.$ with $\left.g=1.25\right)[50,59]$, and $\mathrm{Yb}^{3+}$ ions (theoretical value of $2.57 \mathrm{emu} \cdot \mathrm{K} \cdot \mathrm{mol}^{-1}$ with $g=1.14$ ) $[48,50]$. Upon cooling, the $\chi T$ product of $\left[\mathrm{Dy}(\mathrm{L})(\mathrm{ox})\left(\mathrm{H}_{2} \mathrm{O}\right)\right]$ remains nearly constant until $170 \mathrm{~K}$ and then decreases to $9.90 \mathrm{emu} \cdot \mathrm{K} \cdot \mathrm{mol}^{-1}$ at $1.8 \mathrm{~K}$. For the Ho analogue $\left[\mathrm{Ho}(\mathrm{L})(\mathrm{ox})\left(\mathrm{H}_{2} \mathrm{O}\right)\right]$, the $\chi T$ product decreases slowly between
300 and $100 \mathrm{~K}$, and a steeper decrease is observed from $13.67 \mathrm{emu} \cdot \mathrm{K} \cdot \mathrm{mol}^{-1}$ at $100 \mathrm{~K}$ to $2 \mathrm{emu} \cdot \mathrm{K} \cdot \mathrm{mol}^{-1}$ at $1.8 \mathrm{~K}$. Finally, for the $\mathrm{Yb}$ analogue $\left[\mathrm{Yb}(\mathrm{L})(\mathrm{ox})\left(\mathrm{H}_{2} \mathrm{O}\right)\right]$, the $\chi T$ product decreases slowly as the temperature decreases to reach $1.61 \mathrm{emu} \cdot \mathrm{K} \cdot \mathrm{mol}^{-1}$ at $1.8 \mathrm{~K}$. This behavior is ascribed to the depopulation of the low lying states ( $m_{J}$ states) arising from the ${ }^{6} \mathrm{H}_{5 / 2}\left(\mathrm{Dy}^{3+}\right),{ }^{5} \mathrm{I}_{8}\left(\mathrm{Ho}^{3+}\right)$ and ${ }^{2} \mathrm{~F}_{7 / 2}\left(\mathrm{Yb}^{3+}\right)$, ground states split through the action of the crystal field (for these ions, the ground state is well below the first excited $J$ state). Using the free-ion approach and the isotropic ( $z$ ) component of the susceptibility, the value of the zero-field splitting (ZFS), $\Delta$, was evaluated for each ion using the expressions E2, E3 and E4 in Supporting Information File 1, leading to $\Delta=0.169(3), 0.284(4)$ and $3.25(1) \mathrm{cm}^{-1}$ for $\mathrm{Dy}$, Ho and $\mathrm{Yb}$, respectively. These values are in the range of those reported in the literature [51]. It can be noticed that the introduction of a $z J^{\prime}$ term to fit the magnetic curves down to low temperatures for $\left[\mathrm{Dy}(\mathrm{L})(\mathrm{ox})\left(\mathrm{H}_{2} \mathrm{O}\right)\right]$, $\left[\mathrm{Ho}(\mathrm{L})(\mathrm{ox})\left(\mathrm{H}_{2} \mathrm{O}\right)\right]$ and $\left[\mathrm{Yb}(\mathrm{L})(\mathrm{ox})\left(\mathrm{H}_{2} \mathrm{O}\right)\right]$ compounds did not lead to better results.

\section{Luminescence properties in the solid state}

The excitation spectra of $\left[\mathrm{Gd}(\mathrm{L})(\mathrm{ox})\left(\mathrm{H}_{2} \mathrm{O}\right)\right],\left[\mathrm{Eu}(\mathrm{L})(\mathrm{ox})\left(\mathrm{H}_{2} \mathrm{O}\right)\right]$ and $\left[\mathrm{Tb}(\mathrm{L})(\mathrm{ox})\left(\mathrm{H}_{2} \mathrm{O}\right)\right]$ were recorded at room temperature (ca. $297 \mathrm{~K}$ ) and $12 \mathrm{~K}$ monitoring the ligand emission at $520 \mathrm{~nm}$, and the strongest $\mathrm{Eu}^{3+}{ }^{5} \mathrm{D}_{0} \rightarrow{ }^{7} \mathrm{~F}_{2}$ and $\mathrm{Tb}^{3+}{ }^{5} \mathrm{D}_{4} \rightarrow{ }^{7} \mathrm{~F}_{5}$ transitions (Figure 4). The $\left[\mathrm{Gd}(\mathrm{L})(\mathrm{ox})\left(\mathrm{H}_{2} \mathrm{O}\right)\right]$ excitation spectra consist of three distinct broad UV bands, ranging from 230 to $400 \mathrm{~nm}$, attributed to the $\mathrm{S}_{0} \rightarrow \mathrm{S}_{3,2,1}$ excited transitions of the organic ligand. For $\left[\mathrm{Eu}(\mathrm{L})(\mathrm{ox})\left(\mathrm{H}_{2} \mathrm{O}\right)\right]$, these ligand transitions are

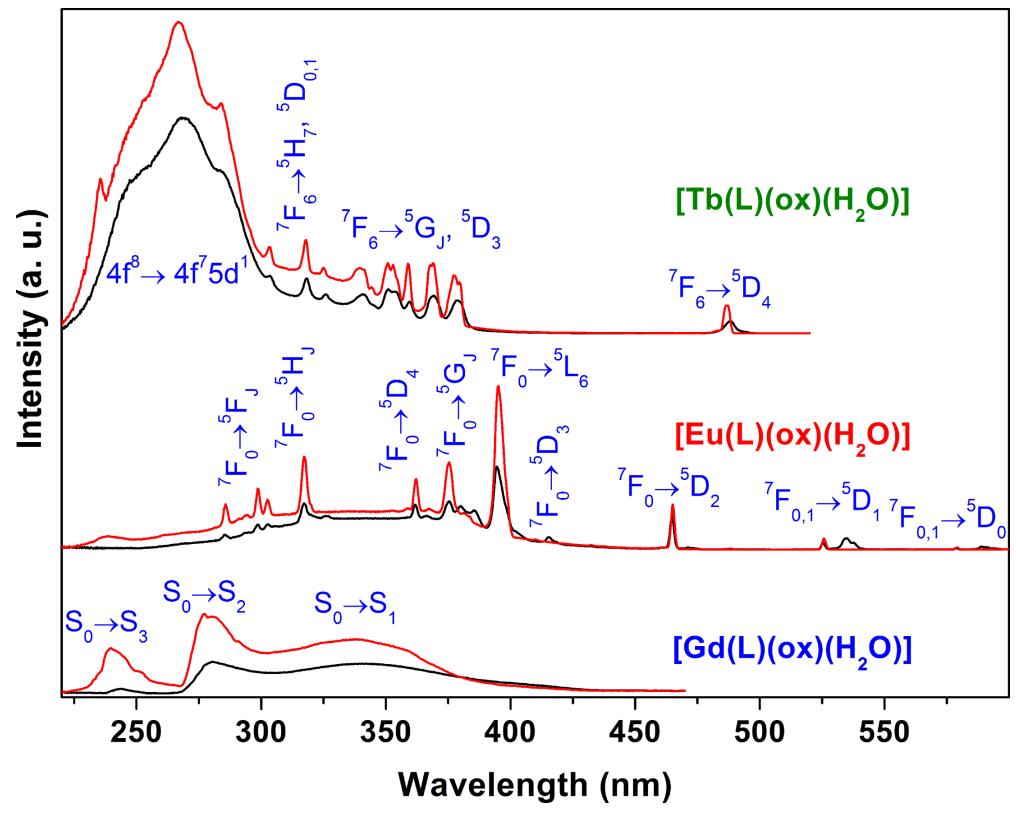

Figure 4: Excitation spectra of $\left[\mathrm{Gd}(\mathrm{L})(\mathrm{ox})\left(\mathrm{H}_{2} \mathrm{O}\right)\right]\left(\lambda_{\mathrm{Em}}=520 \mathrm{~nm}\right)$, $\left[\mathrm{Eu}(\mathrm{L})(\mathrm{ox})\left(\mathrm{H}_{2} \mathrm{O}\right)\right]\left(\lambda_{\mathrm{Em}}=619.6 \mathrm{~nm}\right)$ and $\left[\mathrm{Tb}(\mathrm{L})(\mathrm{ox})\left(\mathrm{H}_{2} \mathrm{O}\right)\right]\left(\lambda_{\mathrm{Em}}=542 \mathrm{~nm}\right) \mathrm{recorded}$ at $297 \mathrm{~K}$ (black lines) and $12 \mathrm{~K}$ (red lines). The intensity is only comparable for the variation of the temperature in each compound. 
partially superimposed with the intra- $4 \mathrm{f}^{6}{ }^{7} \mathrm{~F}_{0,1} \rightarrow{ }^{5} \mathrm{D}_{1-4},{ }^{5} \mathrm{~L}_{6}$, ${ }^{5} \mathrm{G}_{2-6},{ }^{5} \mathrm{H}_{3-7}$ and ${ }^{5} \mathrm{~F}_{1-5}$ transitions of $\mathrm{Eu}^{3+}$, which dominate the corresponding excitation spectra. Finally, the $\left[\mathrm{Tb}(\mathrm{L})(\mathrm{ox})\left(\mathrm{H}_{2} \mathrm{O}\right)\right]$ excitation spectra feature a strong and broad UV band ranging from 220 to ca. $300 \mathrm{~nm}$, with a maximum at $267 \mathrm{~nm}$, which has no counterpart in the $\left[\mathrm{Gd}(\mathrm{L})(\mathrm{ox})\left(\mathrm{H}_{2} \mathrm{O}\right)\right]$ excitation spectra. Thus, this band is attributed to the inter-configurational spinforbiden $4 \mathrm{f}^{8} \rightarrow 4 \mathrm{f}^{7} 5 \mathrm{~d}^{1}$ transition of $\mathrm{Tb}^{3+}$ because its energy is similar to the energy reported for layered $\mathrm{Tb}^{3+}$ silicates [60]. The additional sharp lines in the spectra of $\left[\mathrm{Tb}(\mathrm{L})(\mathrm{ox})\left(\mathrm{H}_{2} \mathrm{O}\right)\right]$ are ascribed to the intra- $4 \mathrm{f}^{8}{ }^{7} \mathrm{~F}_{6} \rightarrow{ }^{5} \mathrm{D}_{2-4},{ }^{5} \mathrm{G}_{\mathrm{J}}$ and ${ }^{5} \mathrm{H}_{7}$ transitions of $\mathrm{Tb}^{3+}$. Although with a lower relevance, the excited states of the ligands also contribute to the entire excitation spectra of $\mathrm{Tb}^{3+}$, as shown below.

The emission spectra of $\left[\mathrm{Gd}(\mathrm{L})(\mathrm{ox})\left(\mathrm{H}_{2} \mathrm{O}\right)\right],\left[\mathrm{Eu}(\mathrm{L})(\mathrm{ox})\left(\mathrm{H}_{2} \mathrm{O}\right)\right]$ and $\left[\mathrm{Tb}(\mathrm{L})(\mathrm{ox})\left(\mathrm{H}_{2} \mathrm{O}\right)\right]$ recorded at $297 \mathrm{~K}$ and $12 \mathrm{~K}$ are given in Figure 5. $\left[\mathrm{Gd}(\mathrm{L})(\mathrm{ox})\left(\mathrm{H}_{2} \mathrm{O}\right)\right]$ displays two broad bands from 390 to ca. $650 \mathrm{~nm}$ attributed to the $\mathrm{S}_{1} \rightarrow \mathrm{S}_{0}$ (peaking at ca. $415 \mathrm{~nm}$ ) fluorescence and $\mathrm{T}_{1} \rightarrow \mathrm{S}_{0}$ (peaking at $503 \mathrm{~nm}$ ) ligand phosphorescence. This assignment is supported by the time-resolved emission spectra recorded at $12 \mathrm{~K}$ excited at $350 \mathrm{~nm}$ (Figure S6, Supporting Information File 1), which demonstrates a much faster time dependence of the $\mathrm{S}_{1} \rightarrow \mathrm{S}_{0}$ transition com- pared to the transition $\mathrm{T}_{1} \rightarrow \mathrm{S}_{0}$. Under $364 \mathrm{~nm}$ excitation, a relative minimum for the $\mathrm{Eu}^{3+}$ and $\mathrm{Tb}^{3+}$ auto-absorption, $\left[\mathrm{Eu}(\mathrm{L})(\mathrm{ox})\left(\mathrm{H}_{2} \mathrm{O}\right)\right]$ and $\left[\mathrm{Tb}(\mathrm{L})(\mathrm{ox})\left(\mathrm{H}_{2} \mathrm{O}\right)\right]$ show mainly the typical sharp $\mathrm{Eu}^{3+}$ and $\mathrm{Tb}^{3+}$ emission lines assigned to the ${ }^{5} \mathrm{D}_{0} \rightarrow{ }^{7} \mathrm{~F}_{0-4}$ and ${ }^{5} \mathrm{D}_{4} \rightarrow{ }^{7} \mathrm{~F}_{6-0}$ transitions, respectively. In addition, both compounds also exhibit a broad band from 400 to ca. $550 \mathrm{~nm}$, particularly weak in the case of the former, attributed to the $\mathrm{S}_{1} \rightarrow \mathrm{S}_{0}$ transition of the ligand. Accordingly, as exemplified in Figure S7 (Supporting Information File 1) with the $\left[\mathrm{Tb}(\mathrm{L})(\mathrm{ox})\left(\mathrm{H}_{2} \mathrm{O}\right)\right]$ time-resolved $12 \mathrm{~K}$ emission spectra, the broad band has a very fast time dependence totally suppressed by a time delay of only $0.05 \mathrm{~ms}$. The suppression of the lowenergy $\mathrm{T}_{1} \rightarrow \mathrm{S}_{0}$ ligand emission denotes an energy transfer from the triplet excited state to the $\mathrm{Eu}^{3+}$ and $\mathrm{Tb}^{3+}$ excited levels. This energy transfer is more effective for the $\mathrm{Eu}^{3+}$ compound, which almost suppresses also the $\mathrm{S}_{1} \rightarrow \mathrm{S}_{0}$ emission. Under excitation at their corresponding maxima, 270 and $395 \mathrm{~nm}$ for $\mathrm{Tb}^{3+}$ and $\mathrm{Eu}^{3+}$, respectively, both $\left[\mathrm{Eu}(\mathrm{L})(\mathrm{ox})\left(\mathrm{H}_{2} \mathrm{O}\right)\right]$ and $\left[\mathrm{Tb}(\mathrm{L})(\mathrm{ox})\left(\mathrm{H}_{2} \mathrm{O}\right)\right]$ show only the respective sharp emission lines (Figure S8; Supporting Information File 1).

The emission of $\mathrm{Eu}^{3+}$ is highly sensitive to slight changes in the first coordination sphere of the metal, and because of this it is widely used as a local probe $[61]$. For $\left[\mathrm{Eu}(\mathrm{L})(\mathrm{ox})\left(\mathrm{H}_{2} \mathrm{O}\right)\right]$, the

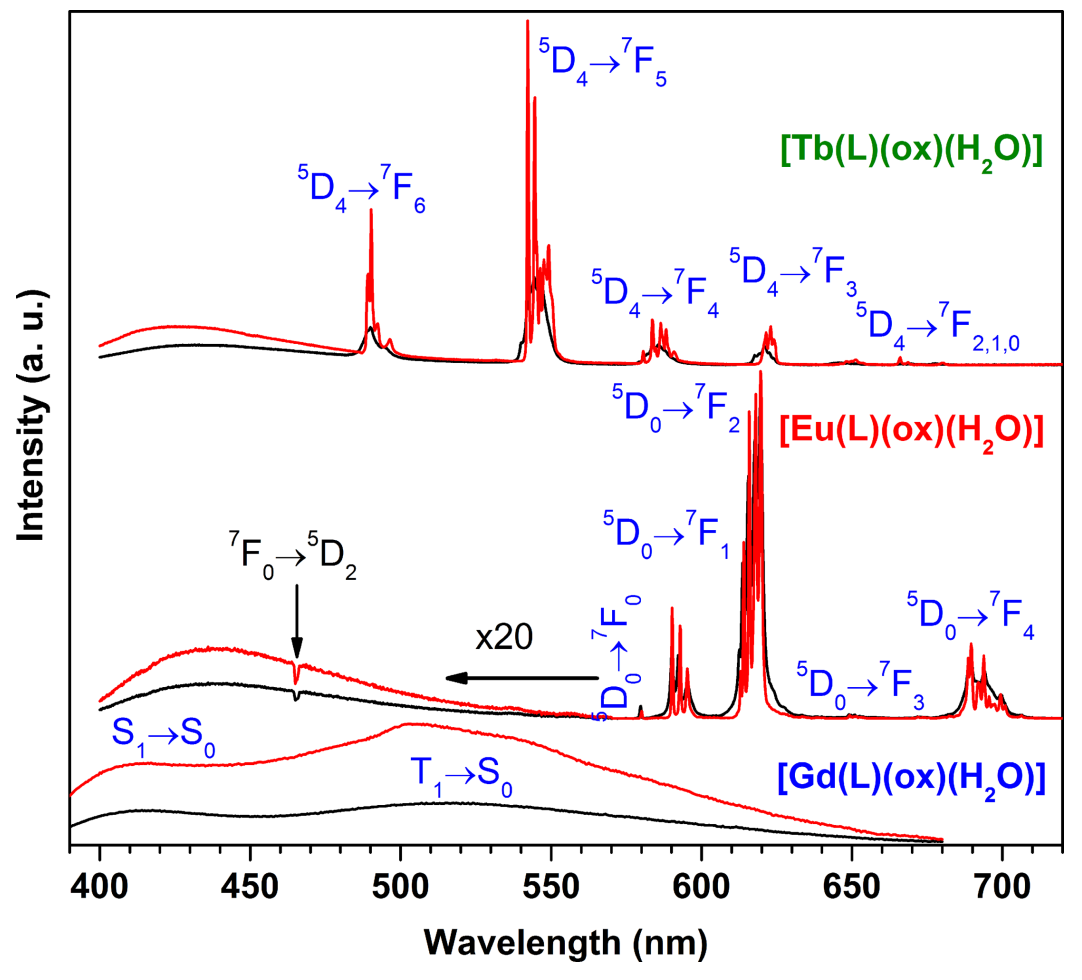

Figure 5: Emission spectra of $\left[\mathrm{Gd}(\mathrm{L})(\mathrm{ox})\left(\mathrm{H}_{2} \mathrm{O}\right)\right]\left(\lambda_{\mathrm{Exc}}=350 \mathrm{~nm}\right)$, $\left[\mathrm{Eu}(\mathrm{L})(\mathrm{ox})\left(\mathrm{H}_{2} \mathrm{O}\right)\right]\left(\lambda_{\mathrm{Exc}}=364 \mathrm{~nm}\right)$ and $\left[\mathrm{Tb}(\mathrm{L})(\mathrm{ox})\left(\mathrm{H}_{2} \mathrm{O}\right)\right]\left(\lambda_{\mathrm{Em}}=364 \mathrm{~nm}\right)$ recorded at $297 \mathrm{~K}$ (black lines) and $12 \mathrm{~K}$ (red lines). The intensity is only comparable for the variation of the temperature in each compound. $\mathrm{For}\left[\mathrm{Eu}(\mathrm{L})(\mathrm{ox})\left(\mathrm{H}_{2} \mathrm{O}\right)\right]$, the negative peak at $465 \mathrm{~nm}$ is due to the Eu ${ }^{3+}$ auto-absorption from the ${ }^{7} \mathrm{~F}_{0} \rightarrow{ }^{5} \mathrm{D}_{2}$ excited transition. 
emission spectra recorded at $297 \mathrm{~K}$ and $12 \mathrm{~K}$ show i) a single ${ }^{5} \mathrm{D}_{0} \rightarrow{ }^{7} \mathrm{~F}_{0}$ transition and a local-field splitting of the ${ }^{7} \mathrm{~F}_{1,2}$ levels into three and five Stark components, respectively; ii) and the predominance of the ${ }^{5} \mathrm{D}_{0} \rightarrow{ }^{7} \mathrm{~F}_{2}$ transition relatively to the ${ }^{5} \mathrm{D}_{0} \rightarrow{ }^{7} \mathrm{~F}_{1}$ one, witnessing the presence of a single lowsymmetry $\mathrm{Eu}^{3+}$ environment, in accordance with the crystal structure. Additionally, the room-temperature $\mathrm{Eu}^{3+5} \mathrm{D}_{0}$ and $\mathrm{Tb}^{3+5} \mathrm{D}_{4}$ decay curves were well fitted by single exponential functions, yielding lifetimes of $0.60 \pm 0.01$ and $0.98 \pm 0.01 \mathrm{~ms}$ for $\left[\mathrm{Eu}(\mathrm{L})(\mathrm{ox})\left(\mathrm{H}_{2} \mathrm{O}\right)\right]$ and $\left[\mathrm{Tb}(\mathrm{L})(\mathrm{ox})\left(\mathrm{H}_{2} \mathrm{O}\right)\right]$, respectively (Figure S9, Supporting Information File 1), corroborating the presence of a unique $\mathrm{Ln}^{3+}$ crystallographic site.

Consideration of these luminescence results prompted the study of isostructural mixed lanthanide networks. In particular, our interest was focused on networks bearing $\mathrm{Tb}^{3+}$ and $\mathrm{Eu}^{3+}$ in view of their potential application in optical thermometry $[17,62]$. Accordingly, four $\mathrm{Tb}^{3+} / \mathrm{Eu}^{3+}$ mixed lanthanide networks of formula $\left[\mathrm{Tb}_{1-x} \mathrm{Eu}_{x}(\mathrm{~L})(\mathrm{ox})\left(\mathrm{H}_{2} \mathrm{O}\right)\right]$ with $x=0.01$, $0.03,0.05$ and 0.10 have been synthesized using the same protocol but varying the molar ratio of $\mathrm{Tb}\left(\mathrm{NO}_{3}\right)_{3} \cdot 6 \mathrm{H}_{2} \mathrm{O}$ and $\mathrm{Eu}\left(\mathrm{NO}_{3}\right)_{3} \cdot 6 \mathrm{H}_{2} \mathrm{O}$. As expected, these mixed lanthanide networks are isostructural with the parent compound $\left[\mathrm{Ln}(\mathrm{L})(\mathrm{ox})\left(\mathrm{H}_{2} \mathrm{O}\right)\right]$ (Figure S10, Supporting Information File 1) and show the presence of $\mathrm{Tb}$ and $\mathrm{Eu}$ in the expected ratio and homogeneously distributed in the crystals (Figure S11, Supporting Information File 1).

Consider the emission spectra of the four $\mathrm{Tb}^{3+} / \mathrm{Eu}^{3+}$ mixed lanthanide networks measured at room temperature (Figure S12, Supporting Information File 1). To maximize the relative poor ligand emission, $364 \mathrm{~nm}$ excitation was used since it corresponds to a maximum of the ligand excitation and to relative minima of both $\mathrm{Eu}^{3+}$ and $\mathrm{Tb}^{3+}$ auto-absorptions, as demonstrated by the selective $12 \mathrm{~K}$ excitation spectra of $\left[\mathrm{Tb}_{0.90} \mathrm{Eu}_{0.10}(\mathrm{~L})(\mathrm{ox})\left(\mathrm{H}_{2} \mathrm{O}\right)\right]$ (Figure S13, Supporting Information File 1). The room-temperature emission spectra of $\left[\mathrm{Tb}_{0.90} \mathrm{Eu}_{0.10}(\mathrm{~L})(\mathrm{ox})\left(\mathrm{H}_{2} \mathrm{O}\right)\right]$ under ambient pressure and after exposure to high vacuum $\left(5 \times 10^{-3} \mathrm{mbar}\right.$, Figure S14, Supporting Information File 1) demonstrates the good stability of the emission of the sample against UV irradiation and pressure change.

Among the four mixed $\mathrm{Tb}^{3+} / \mathrm{Eu}^{3+}$ mixed lanthanide networks, $\left[\mathrm{Tb}_{0.97} \mathrm{Eu}_{0.03}(\mathrm{~L})(\mathrm{ox})\left(\mathrm{H}_{2} \mathrm{O}\right)\right]$ presents at room temperature the best balance between the emissions of ligand, $\mathrm{Tb}^{3+}$ and $\mathrm{Eu}^{3+}$. Based on the integrated areas of the ligand $\left(I_{\mathrm{L}}\right), \mathrm{Tb}^{3+5} \mathrm{D}_{4} \rightarrow{ }^{7} \mathrm{~F}_{5}$ $\left(I_{\mathrm{Tb}}\right)$ and $\mathrm{Eu}^{3+5} \mathrm{D}_{0} \rightarrow{ }^{7} \mathrm{~F}_{2}\left(I_{\mathrm{Eu}}\right)$ emissions, three distinct thermometric parameters may be defined, $\Delta_{1}=I_{\mathrm{Tb}} / I_{\mathrm{Eu}}, \Delta_{2}=I_{\mathrm{Tb}} / I_{\mathrm{L}}$ and $\Delta_{3}=I_{\mathrm{Eu}} / I_{\mathrm{L}}$, allowing for the conversion of the emission intensities into absolute temperature values. The temperature dependence of the $\left[\mathrm{Tb}_{0.97} \mathrm{Eu}_{0.03}(\mathrm{~L})(\mathrm{ox})\left(\mathrm{H}_{2} \mathrm{O}\right)\right]$ emission in the range of $250-340 \mathrm{~K}$ is presented in Figure $6 \mathrm{a}$. Four consecutive emission spectra were collected for each temperature and used to determine the average thermometric parameter, with the errors calculated from the corresponding standard deviation $(95 \%$ confidence). $I_{\mathrm{L}}, I_{\mathrm{Tb}}$ and $I_{\mathrm{Eu}}$ were determined by integrating the emission spectra in the ranges of 392-478 nm, 536-556 and 606-630 nm, respectively. Figure $6 \mathrm{~b}$ depicts the temperature dependence of the three integrated emissions. The emission of the ligand decreases by $58 \%$ from 250 to $340 \mathrm{~K}$, the $\mathrm{Tb}^{3+}$ and $\mathrm{Eu}^{3+}$ emissions decrease by $31 \%$ and by $20 \%$, respectively.

The temperature dependence of the thermometric parameters $\Delta_{1}, \Delta_{2}$ and $\Delta_{3}$ in the range of $250-340 \mathrm{~K}$ is shown in Figure $7 \mathrm{a}$. The corresponding relative sensitivity, defined as $S_{\mathrm{r}}=|\partial \Delta / \partial T| / \Delta$ (a)

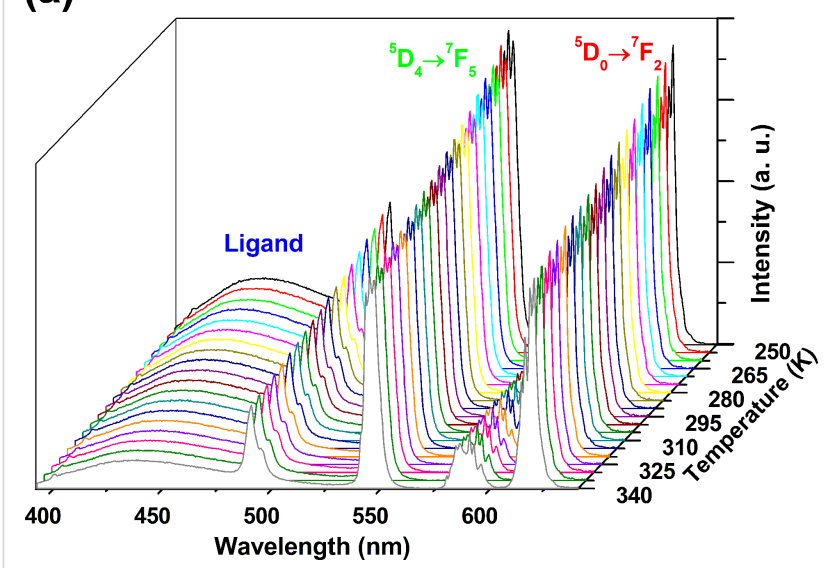

(b)

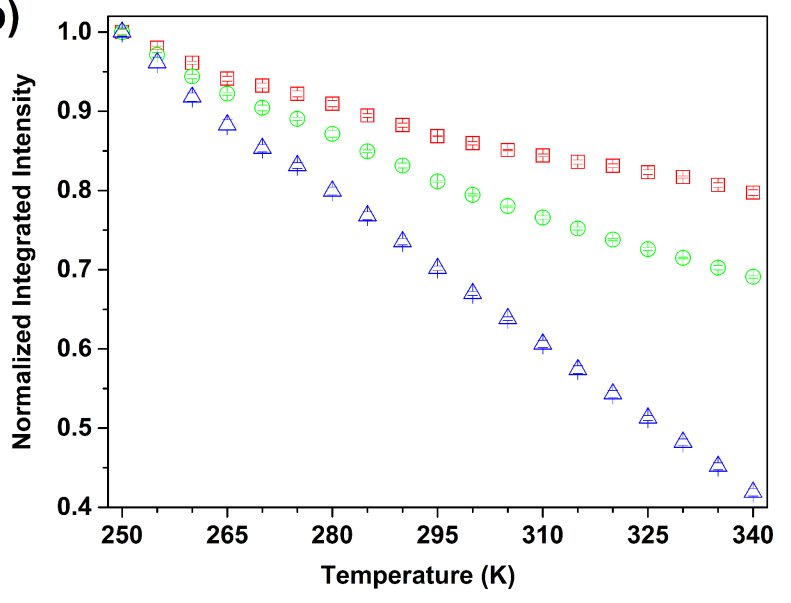

Figure 6: (a) Emission spectra of $\left[\mathrm{Tb}_{0.97} \mathrm{Eu}_{0.03}(\mathrm{~L})(\mathrm{ox})\left(\mathrm{H}_{2} \mathrm{O}\right)\right]$ in the range of 250-340 $\mathrm{K}$ with the excitation fixed at $364 \mathrm{~nm}$, and (b) corresponding temperature dependence of $I_{\mathrm{L}}$ (blue), $I_{\mathrm{Tb}}$ (green) and $I_{\mathrm{Eu}}($ red). 
(a)

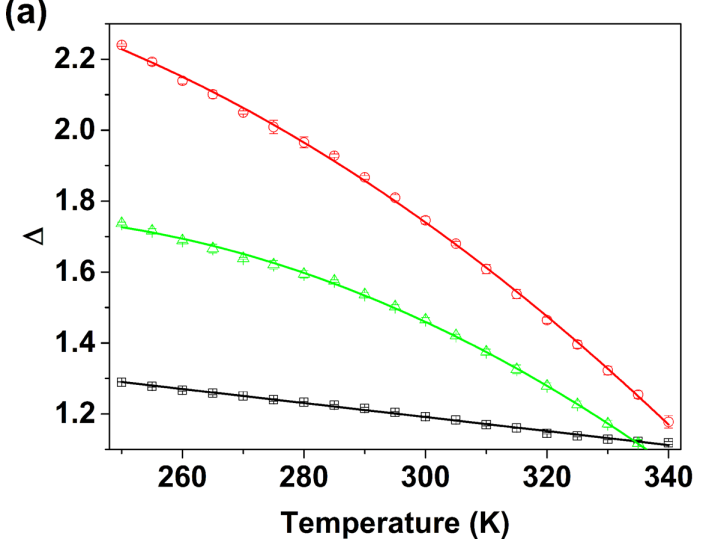

(b)

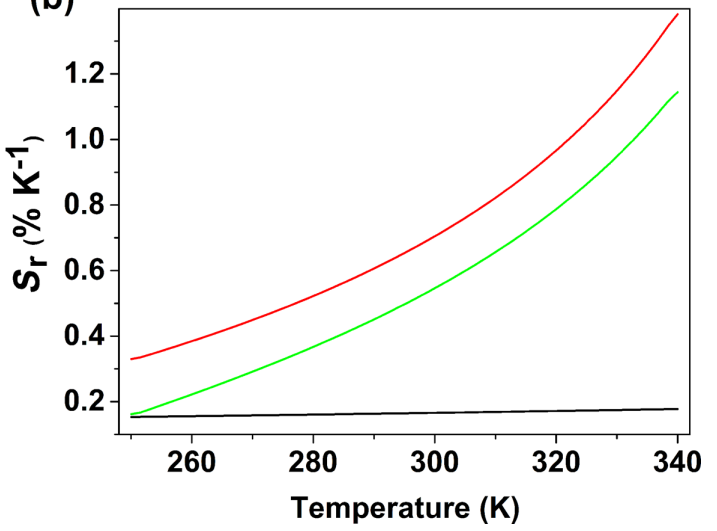

Figure 7: (a) Temperature dependence of $\Delta_{1}$ (black), $\Delta_{2}$ (green) and $\Delta_{3}$ (red) in the range of 250-340 K for [Tb $\left.0.97 \mathrm{Eu}_{0.03}(\mathrm{~L})(\mathrm{ox})\left(\mathrm{H}_{2} \mathrm{O}\right)\right]$. The solid lines are the calibration curves, resulting from the fit considering a linear function for $\Delta_{1}, \Delta(T)=\Delta_{0}+m T\left(r^{2}=0.998\right)$ and second-order polynomial functions, $\Delta(T)=\Delta_{0}+\mathrm{a}_{1} T+\mathrm{a}_{2} T^{2}$, for $\Delta_{2}\left(r^{2}=0.999\right)$ and $\Delta_{3}\left(r^{2}=0.999\right)$. The bars depict the errors in the thermometric parameter resulting from the propagation of the errors determined for $I_{\mathrm{L}}, I_{\mathrm{Tb}}$ and $I_{\mathrm{Eu}}$ and (b) corresponding relative thermal sensitivities in the same temperature range.

[63], a figure of merit used to compare the performance of ratiometric luminescent thermometers, is plotted in Figure $7 \mathrm{~b}$. $\Delta_{2}$ and $\Delta_{3}$ exhibit very good sensitivities in the range of $250-340 \mathrm{~K}$ with maximum relative sensitivities, $S_{\mathrm{m}}$, of $1.14 \%$ and $1.38 \% \cdot \mathrm{K}^{-1}$ at $340 \mathrm{~K}$, respectively. For $\Delta_{1}, S_{\mathrm{m}}$ is only $0.18 \% \cdot \mathrm{K}^{-1}$. The $S_{\mathrm{r}}$ values obtained for $\Delta_{3}$, in particular, are among the highest reported for metal-organic frameworks or MOF-based luminescent thermometers operative in the physiological range. Indeed, to the best of our knowledge, only eight such visible luminescent ratiometric LnMOF thermometers have been reported [64-71], among which two outperform our material $\left[\mathrm{Tb}_{0.97} \mathrm{Eu}_{0.03}(\mathrm{~L})(\mathrm{ox})\left(\mathrm{H}_{2} \mathrm{O}\right)\right]$ : $\mathrm{Tb}_{0.995} \mathrm{Eu}_{0.005} @ \mathrm{In}(\mathrm{OH})\left(2,2^{\prime}\right.$-bipyridine-5,5'-dicarboxylate) with $S_{\mathrm{m}}=4.47 \% \cdot \mathrm{K}^{-1}$ at $333 \mathrm{~K}[65]$ and Eu@UiO-(2,2'-bipyridine-5,5'-dicarboxylate) with $S_{\mathrm{m}}=2.19 \% \cdot \mathrm{K}^{-1}$ at $293 \mathrm{~K}$ [67] (value recalculated and corrected using the published calibration curve). Two other thermometers have a performance similar to ours, $\mathrm{Eu}_{0.089} \mathrm{~Tb}_{0.9911}[2,6$-di(2',4'-dicarboxylphenyl)pyridine] with $S_{\mathrm{m}}=1.39 \% \cdot \mathrm{K}^{-1}$ at $328 \mathrm{~K}$ [70] and $\left[\left(\mathrm{Eu}_{0.231} \mathrm{~Tb}_{0.769} \text { (adipate }\right)_{0.5}\right.$ (phthalate $\left.)\left(\mathrm{H}_{2} \mathrm{O}\right)_{2}\right]$ with $S_{\mathrm{m}}=1.21 \% \cdot \mathrm{K}^{-1}$ at $303 \mathrm{~K}[71]$. These systems are, thus, appealing for potential application as biological sensors $[63,72]$. $\mathrm{The}^{3+} \mathrm{Tb}^{3+}$-to-Eu ${ }^{3+}$ energy transfer plays an important role in the higher sensitivity of $\Delta_{3}\left(I_{\mathrm{Eu}} / I_{\mathrm{L}}\right)$. On the one hand, the $\mathrm{Tb}^{3+}$ lifetimes obtained for $\left[\mathrm{Tb}_{0.97} \mathrm{Eu}_{0.03}(\mathrm{~L})(\mathrm{ox})\left(\mathrm{H}_{2} \mathrm{O}\right)\right]$ from single exponential functions (Figure S15, Supporting Information File 1) decrease from $0.98 \pm 0.01 \mathrm{~ms}$ obtained for the $\mathrm{Tb}^{3+}$-only sample at $297 \mathrm{~K}$ to $0.62 \pm 0.01 \mathrm{~ms}(250 \mathrm{~K})$ and $0.57 \pm 0.01 \mathrm{~ms}$ $(340 \mathrm{~K})$. On the other hand, the $\mathrm{Eu}^{3+}$ lifetimes for the mixed compound (Figure S15, Supporting Information File 1), $0.86 \pm 0.02 \mathrm{~ms}(250 \mathrm{~K})$ and $0.78 \pm 0.01 \mathrm{~ms}(340 \mathrm{~K})$, increases relatively to the one obtained at $297 \mathrm{~K}$ for the $\mathrm{Eu}^{3+}$-only compound $(0.60 \pm 0.01 \mathrm{~ms})$. In addition, the $\mathrm{Eu}^{3+}$ decay curves also exhibit a rise, to $0.81 \pm 0.08 \mathrm{~ms}(250 \mathrm{~K})$ and $0.93 \pm 0.06 \mathrm{~ms}(340 \mathrm{~K})$, most probably originating from the population of the $\mathrm{Eu}^{3+5} \mathrm{D}_{0}$ emitting level trough the $\mathrm{Tb}^{3+5} \mathrm{D}_{4}$ donor level.

\section{Conclusion}

Six novel coordination networks based on an imidazolium dicarboxylate 1,3-(biscarboxymethyl)imidazolium and $\mathrm{Ln}^{3+}$ ions $\left(\mathrm{Ln}=\mathrm{Eu}^{3+}, \mathrm{Gd}^{3+}, \mathrm{Tb}^{3+}, \mathrm{Dy}^{3+}, \mathrm{Ho}^{3+}\right.$ and $\left.\mathrm{Yb}^{3+}\right)$ in the presence of oxalate have been obtained by solvothermal reaction and totally characterized. These coordination networks are isostructural and present a monoclinic structure (space group $P 2_{1} / a$ ). They exhibit magnetic and luminescent properties that are characteristic for the considered lanthanide ions (except for compounds based on $\mathrm{Gd}^{3+}$ ions). The possibility to obtain $\mathrm{Tb}^{3+} / \mathrm{Eu}^{3+}$ mixed lanthanide networks has been exploited for potential application in thermometry. Accordingly, four mixed lanthanide networks $\left[\mathrm{Tb}_{1-x} \mathrm{Eu}_{x}(\mathrm{~L})(\mathrm{ox})\left(\mathrm{H}_{2} \mathrm{O}\right)\right](x=0.01,0.03$, 0.05 and 0.10 ) were synthesized with different $\mathrm{Tb}^{3+} / \mathrm{Eu}^{3+}$ ratios. Using as the thermometric parameter the ratio between the $\mathrm{Eu}^{3+},{ }^{5} \mathrm{D}_{0} \rightarrow{ }^{7} \mathrm{~F}_{2}$ transition, and the ligand emissions, $\left[\mathrm{Tb}_{0.97} \mathrm{Eu}_{0.03}(\mathrm{~L})_{2}(\mathrm{ox})\left(\mathrm{H}_{2} \mathrm{O}\right)\right]$ was found to be one of the best three luminescent ratiometric LnMOF thermometers, operative in the physiological range with a maximum sensitivity of $1.38 \% \cdot \mathrm{K}^{-1}$ at $340 \mathrm{~K}$. The fact that the structure and properties of these coordination networks can be predicted by design constitutes a promising approach to new multifunctional materials, especially magnetic and luminescent, materials.

\section{Experimental Synthesis}

Glycine, paraformaldehyde, oxalic acid, $\mathrm{Nd}\left(\mathrm{NO}_{3}\right)_{3} \cdot 6 \mathrm{H}_{2} \mathrm{O}$, $\mathrm{Sm}\left(\mathrm{NO}_{3}\right)_{3} \cdot 6 \mathrm{H}_{2} \mathrm{O}, \mathrm{Eu}\left(\mathrm{NO}_{3}\right)_{3} \cdot 6 \mathrm{H}_{2} \mathrm{O}, \mathrm{Gd}\left(\mathrm{NO}_{3}\right)_{3} \cdot 6 \mathrm{H}_{2} \mathrm{O}$, 
$\mathrm{Tb}\left(\mathrm{NO}_{3}\right)_{3} \cdot 6 \mathrm{H}_{2} \mathrm{O}, \mathrm{Dy}\left(\mathrm{NO}_{3}\right)_{3} \cdot 5 \mathrm{H}_{2} \mathrm{O}, \mathrm{Ho}\left(\mathrm{NO}_{3}\right)_{3} \cdot 5 \mathrm{H}_{2} \mathrm{O}$ and $\mathrm{Yb}\left(\mathrm{NO}_{3}\right)_{3} \cdot x \mathrm{H}_{2} \mathrm{O}$ were purchased from Alfa Aesar and were used as received.

[HL] was synthesized according protocols published in the literature $[41,42]$. Synthesis method and characterizations (elemental analysis, ${ }^{1} \mathrm{H}$ and ${ }^{13} \mathrm{C}$ NMR) can be found in a previously published paper [31].

$\left[\mathrm{Ln}(\mathrm{L})(\mathrm{ox})\left(\mathrm{H}_{2} \mathrm{O}\right)\right]$ compounds with $\mathrm{Ln}=\mathrm{Eu}^{3+}, \mathrm{Gd}^{3+}, \mathrm{Tb}^{3+}$, $\mathrm{Dy}^{3+}, \mathrm{Ho}^{3+}$ and $\mathrm{Yb}^{3+}$ were prepared by solvothermal reaction by mixing [HL] $(0.5 \mathrm{mmol})$, lanthanide nitrate $(0.5 \mathrm{mmol})$ and oxalic acid $(0.25 \mathrm{mmol})$ in a water/ethanol solution $(1.5 \mathrm{~mL})$. The solution was sealed in a Teflon-line stainless steel bomb $(6 \mathrm{~mL})$ and heated at $393 \mathrm{~K}$ for $72 \mathrm{~h}$. After cooling to room temperature, the bomb was opened and colorless crystals were filtered and washed with ethanol and dried at room temperature. Yields were between $41 \%$ and 59\%. Elemental analysis confirmed the composition of each compounds. $\left[\mathrm{Eu}(\mathrm{L})(\mathrm{ox})\left(\mathrm{H}_{2} \mathrm{O}\right)\right]$ : Anal. calcd for $\mathrm{C}_{9} \mathrm{H}_{9} \mathrm{~N}_{2} \mathrm{O}_{9} \mathrm{Eu}\left(440.96 \mathrm{~g} \cdot \mathrm{mol}^{-1}\right)$ : C, 24.49; $\mathrm{H}$, 2.04; N, 6.35; found: C, 24.01; H, 2.06; N, 6.00; $\left[\mathrm{Gd}(\mathrm{L})(\mathrm{ox})\left(\mathrm{H}_{2} \mathrm{O}\right)\right]$ : anal. calcd for $\mathrm{C}_{9} \mathrm{H}_{9} \mathrm{~N}_{2} \mathrm{O}_{9} \mathrm{Gd}(446.25$ $\left.\mathrm{g} \cdot \mathrm{mol}^{-1}\right)$ : C, 24.20; H, 2.02; N, 6.27; found: C, 23.96; H, 2.05; $\mathrm{N}, 6.24 ;\left[\mathrm{Tb}(\mathrm{L})(\mathrm{ox})\left(\mathrm{H}_{2} \mathrm{O}\right)\right]$ : anal. calcd for $\mathrm{C}_{9} \mathrm{H}_{9} \mathrm{~N}_{2} \mathrm{O}_{9} \mathrm{~Tb}$ (447.92 $\left.\mathrm{g} \cdot \mathrm{mol}^{-1}\right)$ : C, 24.11; H, 2.01; N, 6.25; found: C, 23.68; $\mathrm{H}, 2.07 ; \mathrm{N}, 6.10$; [Dy $\left.(\mathrm{L})(\mathrm{ox})\left(\mathrm{H}_{2} \mathrm{O}\right)\right]$ : anal. calcd for $\mathrm{C}_{9} \mathrm{H}_{9} \mathrm{~N}_{2} \mathrm{O}_{9}$ Dy $\left(451.50 \mathrm{~g} \cdot \mathrm{mol}^{-1}\right)$ : C, 23.92; H, 1.99; N, 6.20; found: C, 23.47; H, 2.05; N, 6.15; [Ho(L)(ox) $\left.\left(\mathrm{H}_{2} \mathrm{O}\right)\right]$ : anal. calcd for $\mathrm{C}_{9} \mathrm{H}_{9} \mathrm{~N}_{2} \mathrm{O}_{9} \mathrm{Ho}\left(453.93 \mathrm{~g} \cdot \mathrm{mol}^{-1}\right)$ : C, 23.79; $\mathrm{H}, 1.98 ; \mathrm{N}$, 6.17; found: C, 23.16; H, 2.03; N, 6.05; [Yb(L)(ox) $\left.\left(\mathrm{H}_{2} \mathrm{O}\right)\right]$ : anal. calcd for $\mathrm{C}_{9} \mathrm{H}_{9} \mathrm{~N}_{2} \mathrm{O}_{9} \mathrm{Yb}\left(462.04 \mathrm{~g} \cdot \mathrm{mol}^{-1}\right)$ : C, 23.37; $\mathrm{H}$, 1.95 ; N, 6.06; found: C, 23.08; H, 2.10; N 5.95.

$\left[\mathrm{Tb}_{1-x} \mathrm{Eu}_{x}(\mathrm{~L})(\mathrm{ox})\left(\mathrm{H}_{2} \mathrm{O}\right)\right]$ compounds with $x=0.01,0.03,0.05$ and 0.10 were prepared in a similar manner but terbium nitrate and europium nitrate were introduced with the adapted stoichiometry. Yields were between $32 \%$ and $34 \%$.

\section{Physical measurements}

Elemental analyses for C, H, N were carried out at the Service de Microanalyses of the Institut de Chimie de Strasbourg. The SEM images were obtained with a JEOL 6700F (scanning electron microscope (SEM) equipped with a field-emission gun (FEG), operating at $3 \mathrm{kV}$ in the SEI mode instrument. FTIR spectra were collected on a Perkin Elmer Spectrum Two UATR-FTIR spectrometer. TGA-TDA experiments were performed using a TA instrument SDT Q600 (heating rates of $5{ }^{\circ} \mathrm{C} \cdot \mathrm{min}^{-1}$ under air stream). NMR spectra in solution were recorded using a Bruker AVANCE $300(300 \mathrm{MHz})$ spectrometer. The emission and excitation spectra were recorded on a modular double grating excitation spectrofluorometer with a
TRIAX 320 emission monochromator (Fluorolog-3, Horiba Scientific) coupled to a R928 or a H9170 Hamamatsu photomultiplier, for the detection on the visible and near-infrared spectral ranges, respectively, using the front-face acquisition mode. The excitation source was a $450 \mathrm{~W}$ Xe arc lamp. The emission spectra were corrected for detection and optical spectral response of the spectrofluorometer and the excitation spectra were corrected for the spectral distribution of the lamp intensity using a photodiode reference detector. Time-resolved measurements were carried out with the pulsed Xe-Hg lamp excitation, in front-face acquisition mode. The temperature was controlled with a helium closed-cycle cryostat with vacuum system (ca. $5 \times 10^{-6}$ mbar) and a Lakeshore 330 auto-tuning temperature controller with a resistive heater. The temperature can be adjusted from ca. 12 to $450 \mathrm{~K}$ with a maximum accuracy of $0.1 \mathrm{~K}$. The sample temperature was fixed to a particular value using the auto-tuning temperature controller; after waiting 5 min to thermalize the sample, four consecutive steady-state emission spectra were measured for each temperature; the maximum temperature difference detected during the acquisitions was $0.1 \mathrm{~K}$, the temperature accuracy of the controller. Magnetic measurements were performed using a Quantum Design SQUID-VSM magnetometer. The static susceptibility measurements were performed in the temperature range of $1.8-300 \mathrm{~K}$ with an applied field of $0.5 \mathrm{~T}$. Samples were blocked in eicosane to avoid orientation under magnetic field. Magnetization measurements at different fields and at given temperature confirm the absence of ferromagnetic impurities. Data were corrected for the sample holder and eicosane and diamagnetism was estimated from Pascal constants. The powder XRD patterns were collected with a Bruker D8 diffractometer $\left(\mathrm{Cu} \mathrm{K} \alpha_{1}\right.$, $\lambda=1.540598 \AA$ ) operating at $40 \mathrm{kV}$ and $40 \mathrm{~mA}$ equipped with a LynxEye detector. The X-ray diffraction data on single crystal were collected with graphite-monochromatized Mo $\mathrm{K} \alpha$ radiation $(\lambda=0.71073 \AA)$ with a Kappa Nonius CCD diffractometer at room temperature. Intensity data were corrected for Lorenzpolarization and absorption factors. The structures were solved by direct methods using SIR92 [73], and refined against $F^{2}$ by full-matrix least-squares methods using SHELXL-2014 with anisotropic displacement parameters for all non-hydrogen atoms $[74,75]$. All calculations were performed by using the crystal structure crystallographic software package WINGX [76]. The structure was drawn using Mercury or Diamond [77,78]. Hydrogen atoms were located on a difference Fourier map and introduced into the calculations as a riding model with isotropic thermal parameters. Crystallographic data for the structures reported have been deposited in the Cambridge Crystallographic Data Centre with CCDC reference numbers 1541843, 1541844, $1541845,1541846,1541847,1541848$ for $\left[\mathrm{Gd}(\mathrm{L})(\mathrm{ox})\left(\mathrm{H}_{2} \mathrm{O}\right)\right]$, $\left[\mathrm{Yb}(\mathrm{L})(\mathrm{ox})\left(\mathrm{H}_{2} \mathrm{O}\right)\right]$, [Dy $\left.(\mathrm{L})(\mathrm{ox})\left(\mathrm{H}_{2} \mathrm{O}\right)\right]$, [Ho(L) $\left.(\mathrm{ox})\left(\mathrm{H}_{2} \mathrm{O}\right)\right]$, $\left[\mathrm{Tb}(\mathrm{L})(\mathrm{ox})\left(\mathrm{H}_{2} \mathrm{O}\right)\right],\left[\mathrm{Eu}(\mathrm{L})(\mathrm{ox})\left(\mathrm{H}_{2} \mathrm{O}\right)\right]$. 


\section{Supporting Information}

Supporting Information contains a representation of the coordination polyhedron, a table of selected bonds, a comparison of the experimental powder X-ray diffraction patterns of the different compounds and the simulated pattern from single crystals X-ray data, SEM analysis, TGA/TDA analysis, a summary of the weight loss values for the different compounds, infrared spectra, luminescence measurement and magnetic expression.

\section{Supporting Information File 1}

Additional experimental data.

[https://www.beilstein-journals.org/bjnano/content/ supplementary/2190-4286-9-259-S1.pdf]

\section{Acknowledgements}

The authors thank the Centre National de la Recherche Scientifique (CNRS), the Universite de Strasbourg (Idex), the Labex NIE (ANR-11-LABX-0058_NIE within the Investissement d'Avenir program ANR-10-IDEX-0002-02), the Agence Nationale de la Recherche (ANR contract no. ANR-15-CE080020-01) and the icFRC (http://www.icfrc.fr) for funding. Part of the present work comes from the thesis of Pierre Farger [32] and is part of the research activity supported by the European COST action MP1202: HINT (Rational design of hybrid organic-inorganic interfaces: the next step towards advanced functional materials. http://www.cost-hint.cnrs.fr). This work was also developed within the scope of the project CICECOAveiro Institute of Materials, POCI-01-0145-FEDER-007679 (Fundação para a Ciência e a Tecnologia, FCT, Ref. UID/CTM/ 50011/2013), financed by national funds through the FCT/MEC (Ministério da Educação e Ciência) and when appropriate co-financed by FEDER under the PT2020 Partnership Agreement. D.A. (SFRH/BPD/95032/2013) thanks FCT for a postdoctoral grant. The authors are grateful to Didier Burger for technical assistance.

\section{ORCID ${ }^{\circledR}$ iDs}

Guillaume Rogez - https://orcid.org/0000-0001-9006-7273 Duarte Ananias - https://orcid.org/0000-0003-4394-045X Emilie Delahaye - https://orcid.org/0000-0001-9114-1682

\section{References}

1. Moghadam, P. Z.; Li, A.; Wiggin, S. B.; Tao, A.; Maloney, A. G. P.; Wood, P. A.; Ward, S. C.; Fairen-Jimenez, D. Chem. Mater. 2017, 29, 2618-2625. doi:10.1021/acs.chemmater.7b00441

2. Zhao, Y. Chem. Mater. 2016, 28, 8079-8081. doi:10.1021/acs.chemmater.6b04677

3. Li, S.; Huo, F. Nanoscale 2015, 7, 7482-7501. doi:10.1039/c5nr00518c
4. Pagis, C.; Ferbinteanu, M.; Rothenberg, G.; Tanase, S. ACS Catal. 2016, 6, 6063-6072. doi:10.1021/acscatal.6b01935

5. Yi, F.-Y.; Chen, D.; Wu, M.-K.; Han, L.; Jiang, H.-L. ChemPlusChem 2016, 81, 675-690. doi:10.1002/cplu.201600137

6. Yao, Q.; Bermejo Gómez, A.; Su, J.; Pascanu, V.; Yun, Y.; Zheng, H.; Chen, H.; Liu, L.; Abdelhamid, H. N.; Martín-Matute, B.; Zou, X. Chem. Mater. 2015, 27, 5332-5339. doi:10.1021/acs.chemmater.5b01711

7. Li, H.-Y.; Wei, Y.-L.; Dong, X.-Y.; Zang, S.-Q.; Mak, T. C. W. Chem. Mater. 2015, 27, 1327-1331. doi:10.1021/cm504350q

8. Li, B.; Wen, H.-M.; Cui, Y.; Qian, G.; Chen, B. Prog. Polym. Sci. 2015, 48, 40-84. doi:10.1016/j.progpolymsci.2015.04.008

9. Hu, Z.; Deibert, B. J.; Li, J. Chem. Soc. Rev. 2014, 43, 5815-5840. doi:10.1039/c4cs00010b

10. Cui, Y.; Chen, B.; Qian, G. Coord. Chem. Rev. 2014, 273-274, 76-86. doi:10.1016/j.ccr.2013.10.023

11. Cui, Y.; Yue, Y.; Qian, G.; Chen, B. Chem. Rev. 2012, 112, 1126-1162. doi:10.1021/cr200101d

12. Rocha, J.; Carlos, L. D.; Paz, F. A. A.; Ananias, D. Chem. Soc. Rev. 2011, 40, 926-940. doi:10.1039/c0cs00130a

13. Heine, J.; Müller-Buschbaum, K. Chem. Soc. Rev. 2013, 42, 9232. doi:10.1039/c3cs60232j

14. Allendorf, M. D.; Bauer, C. A.; Bhakta, R. K.; Houk, R. J. T. Chem. Soc. Rev. 2009, 38, 1330-1352. doi:10.1039/b802352m

15. Amghouz, Z.; García-Granda, S.; García, J. R.; Ferreira, R. A. S.; Mafra, L.; Carlos, L. D.; Rocha, J. Inorg. Chem. 2012, 51, 1703-1716. doi:10.1021/ic202020z

16. Fordham, S.; Wang, X.; Bosch, M.; Zhou, H.-C. Lanthanide Metal-Organic Frameworks: Syntheses, Properties, and Potential Applications. In Lanthanide Metal-Organic Frameworks; Cheng, P., Ed.; Structure and Bonding; Springer: Berlin, Germany, 2014; pp 1-27. doi:10.1007/430_2014_162

17. Rocha, J.; Brites, C. D. S.; Carlos, L. D. Chem. - Eur. J. 2016, 22 , 14782-14795. doi:10.1002/chem.201600860

18. Wang, Z.; Ananias, D.; Carné-Sánchez, A.; Brites, C. D. S.; Imaz, I.; Maspoch, D.; Rocha, J.; Carlos, L. D. Adv. Funct. Mater. 2015, 25 , 2824-2830. doi:10.1002/adfm.201500518

19. García-García, A.; Oyarzabal, I.; Cepeda, J.; Seco, J. M.; García-Valdivia, A. A.; Gómez-Ruiz, S.; Salinas-Castillo, A.; Choquesillo-Lazarte, D.; Rodríguez-Diéguez, A. New J. Chem. 2018, 42, 832-837. doi:10.1039/c7nj02935g

20. Oyarzabal, I.; Fernández, B.; Cepeda, J.; Gómez-Ruiz, S.; Calahorro, A. J.; Seco, J. M.; Rodríguez-Diéguez, A. CrystEngComm 2016, 18, 3055-3063. doi:10.1039/c6ce00318d

21. Seco, J. M.; Oyarzabal, I.; Pérez-Yáñez, S.; Cepeda, J.; Rodríguez-Diéguez, A. Inorg. Chem. 2016, 55, 11230-11248. doi:10.1021/acs.inorgchem.6b01845

22. Liu, K.; Li, H.; Zhang, X.; Shi, W.; Cheng, P. Inorg. Chem. 2015, 54, 10224-10231. doi:10.1021/acs.inorgchem.5b01356

23. Chen, M.; Sañudo, E. C.; Jiménez, E.; Fang, S.-M.; Liu, C.-S.; Du, M. Inorg. Chem. 2014, 53, 6708-6714. doi:10.1021/ic500490x

24. Decadt, R.; Van Hecke, K.; Depla, D.; Leus, K.; Weinberger, D.; Van Driessche, I.; Van Der Voort, P.; Van Deun, R. Inorg. Chem. 2012, 51, 11623-11634. doi:10.1021/ic301544q

25. Ma, R.; Chu, H.; Zhao, Y.; Wuren, Q.; Shan, M. Spectrochim. Acta, Part A 2010, 77, 419-423. doi:10.1016/j.saa.2010.06.005

26. Wang, P.; Fan, R.-Q.; Liu, X.-R.; Wang, L.-Y.; Yang, Y.-L.; Cao, W.-W.; Yang, B.; Hasi, W.; Su, Q.; Mu, Y. CrystEngComm 2013, 15, 1931-1949. doi:10.1039/c3ce26684b 
27. Chai, X.-C.; Sun, Y.-Q.; Lei, R.; Chen, Y.-P.; Zhang, S.; Cao, Y.-N.; Zhang, H.-H. Cryst. Growth Des. 2010, 10, 658-668. doi:10.1021/cg901075r

28. Sequeira, G. M.; Tan, W. Y.; Moore, E. G. Dalton Trans. 2015, 44, 13378-13383. doi:10.1039/c5dt01875g

29. Abrahams, B. F.; Maynard-Casely, H. E.; Robson, R.; White, K. F. CrystEngComm 2013, 15, 9729-9737. doi:10.1039/c3ce41226a

30. Han, L.; Zhang, S.; Wang, Y.; Yan, X.; Lu, X. Inorg. Chem. 2009, 48, 786-788. doi:10.1021/ic800632r

31. Farger, P.; Leuvrey, C.; Gallart, M.; Gilliot, P.; Rogez, G.; Rabu, P.; Delahaye, E. Magnetochemistry 2017, 3, No. 1. doi:10.3390/magnetochemistry3010001

32. Farger, $P$. Synthèse lonothermale de Réseaux Hybrides Multiferroïques. Ph.D. Thesis, Université de Strasbourg, Strasbourg, France, 2016.

33. Farger, P.; Guillot, R.; Leroux, F.; Parizel, N.; Gallart, M.; Gilliot, P.; Rogez, G.; Delahaye, E.; Rabu, P. Eur. J. Inorg. Chem. 2015, 5342-5350. doi:10.1002/ejic.201500825

34. Martin, N. P.; Falaise, C.; Volkringer, C.; Henry, N.; Farger, P.; Falk, C.; Delahaye, E.; Rabu, P.; Loiseau, T. Inorg. Chem. 2016, 55, 8697-8705. doi:10.1021/acs.inorgchem.6b01232

35. Calderone, P. J.; Forster, P. M.; Borkowski, L. A.; Teat, S. J.; Feygenson, M.; Aronson, M. C.; Parise, J. B. Inorg. Chem. 2011, 50, 2159-2167. doi:10.1021/ic1015548

36. Ji, W.-J.; Zhai, Q.-G.; Li, S.-N.; Jiang, Y.-C.; Hu, M.-C. Chem. Commun. 2011, 47, 3834-3836. doi:10.1039/c0cc04890a

37. Morris, R. E. Chem. Commun. 2009, 2990-2998. doi:10.1039/b902611h

38. Xu, L.; Yan, S.; Choi, E.-Y.; Lee, J. Y.; Kwon, Y.-U. Chem. Commun. 2009, 3431-3433. doi:10.1039/b902223f

39. Zhang, J.; Chen, S.; Bu, X. Angew. Chem., Int. Ed. 2008, 47, 5434-5437. doi:10.1002/anie.200801838

40. Xu, L.; Choi, E.-Y.; Kwon, Y.-U. Inorg. Chem. 2007, 46, 10670-10680. doi:10.1021/ic701393w

41. Fei, Z.; Zhao, D.; Geldbach, T. J.; Scopelliti, R.; Dyson, P. J. Chem. - Eur. J. 2004, 10, 4886-4893. doi:10.1002/chem.200400145

42. Kühl, O.; Palm, G. Tetrahedron: Asymmetry 2010, 21, 393-397. doi:10.1016/j.tetasy.2010.02.015

43. Deng, Z.-P.; Kang, W.; Huo, L.-H.; Zhao, H.; Gao, S. Dalton Trans. 2010, 39, 6276-6284. doi:10.1039/c0dt00031k

44. Wang, X.-J.; Cen, Z.-M.; Ni, Q.-L.; Jiang, X.-F.; Lian, H.-C.; Gui, L.-C.; Zuo, H.-H.; Wang, Z.-Y. Cryst. Growth Des. 2010, 10, 2960-2968. doi:10.1021/cg1000045

45. Zhao, X.-Q.; Liu, X.-H.; Li, J.-J.; Zhao, B. CrystEngComm 2013, 15, 3308-3317. doi:10.1039/c2ce26695d

46. Dendrinou-Samara, C.; Tsotsou, G.; Ekateriniadou, L. V.; Kortsaris, A. H.; Raptopoulou, C. P.; Terzis, A.; Kyriakidis, D. A.; Kessissoglou, D. P. J. Inorg. Biochem. 1998, 71, 171-179. doi:10.1016/s0162-0134(98)10051-x

47. Deacon, G. B.; Phillips, R. J. Coord. Chem. Rev. 1980, 33, 227-250. doi:10.1016/s0010-8545(00)80455-5

48. Kahn, O. Molecular Magnetism; Wiley-VCH: Weinheim, Germany, 1993.

49. Fisher, M. E. Am. J. Phys. 1964, 32, 343-346. doi:10.1119/1.1970340

50. Benelli, C.; Gatteschi, D. Chem. Rev. 2002, 102, 2369-2388. doi:10.1021/cr010303r

51. Cepeda, J.; Balda, R.; Beobide, G.; Castillo, O.; Fernández, J.; Luque, A.; Pérez-Yáñez, S.; Román, P. Inorg. Chem. 2012, 51, 7875-7888. doi:10.1021/ic3009392
52. Cañadillas-Delgado, L.; Pasán, J.; Fabelo, O.; Hernández-Molina, M.; Lloret, F.; Julve, M.; Ruiz-Pérez, C. Inorg. Chem. 2006, 45, 10585-10594. doi:10.1021/ic061173d

53. Han, Z.-B.; Zhang, G.-X.; Zeng, M.-H.; Ge, C.-H.; Zou, X.-H.; Han, G.-X. CrystEngComm 2009, 11, 2629-2633. doi:10.1039/b905663g

54. Lhoste, J.; Pérez-Campos, A.; Henry, N.; Loiseau, T.; Rabu, P.; Abraham, F. Dalton Trans. 2011, 40, 9136-9144. doi:10.1039/c1dt10485c

55. Andruh, M.; Bakalbassis, E.; Kahn, O.; Trombe, J. C.; Porcher, P. Inorg. Chem. 1993, 32, 1616-1622. doi:10.1021/ic00061a017

56. Boča, R. Theoretical Foundations of Molecular Magnetism; Elsevier: Amsterdam, Netherlands, 1999.

57. Amar, N. B.; Hassairi, M. A.; Dammak, M. J. Lumin. 2016, 173, 223-230. doi:10.1016/j.jlumin.2016.01.023

58. Liu, G. K.; Carnall, W. T.; Jones, R. P.; Cone, R. L.; Huang, J. J. Alloys Compd. 1994, 207-208, 69-73. doi:10.1016/0925-8388(94)90179-1

59. Bernini, M. C.; Brusau, E. V.; Narda, G. E.; Echeverria, G. E.; Pozzi, C. G.; Punte, G.; Lehmann, C. W. Eur. J. Inorg. Chem. 2007, 684-693. doi:10.1002/ejic.200600860

60. Ananias, D.; Kostova, M.; Almeida Paz, F. A.; Ferreira, A.; Carlos, L. D.; Klinowski, J.; Rocha, J. J. Am. Chem. Soc. 2004, 126, 10410-10417. doi:10.1021/ja047905n

61. Bünzli, J.-C. G.; Choppin, G. R. Lanthanide Probes in Life, Chemical and Earth Sciences; Elsevier: Amsterdam, Netherlands, 1989; pp $22 \mathrm{ff}$.

62. Cui, Y.; Xu, H.; Yue, Y.; Guo, Z.; Yu, J.; Chen, Z.; Gao, J.; Yang, Y.; Qian, G.; Chen, B. J. Am. Chem. Soc. 2012, 134, 3979-3982. doi:10.1021/ja2108036

63. Brites, C. D. S.; Lima, P. P.; Silva, N. J. O.; Millán, A.; Amaral, V. S.; Palacio, F.; Carlos, L. D. Nanoscale 2012, 4, 4799-4829. doi:10.1039/c2nr30663h

64. Cadiau, A.; Brites, C. D. S.; Costa, P. M. F. J.; Ferreira, R. A. S.; Rocha, J.; Carlos, L. D. ACS Nano 2013, 7, 7213-7218. doi:10.1021/nn402608w

65. Zhou, Y.; Yan, B.; Lei, F. Chem. Commun. 2014, 50, 15235-15238. doi:10.1039/c4cc07038k

66. Cui, Y.; Song, R.; Yu, J.; Liu, M.; Wang, Z.; Wu, C.; Yang, Y.; Wang, Z.; Chen, B.; Qian, G. Adv. Mater. 2015, 27, 1420-1425. doi:10.1002/adma.201404700

67. Zhou, Y.; Yan, B. J. Mater. Chem. C 2015, 3, 9353-9358. doi:10.1039/c5tc02004b

68. Zhao, D.; Rao, X.; Yu, J.; Cui, Y.; Yang, Y.; Qian, G. Inorg. Chem. 2015, 54, 11193-11199. doi:10.1021/acs.inorgchem.5b01623

69. Li, L.; Zhu, Y.; Zhou, X.; Brites, C. D. S.; Ananias, D.; Lin, Z.; Paz, F. A. A.; Rocha, J.; Huang, W.; Carlos, L. D. Adv. Funct. Mater. 2016, 26, 8677-8684. doi:10.1002/adfm.201603179

70. Yang, Y.; Chen, L.; Jiang, F.; Yu, M.; Wan, X.; Zhang, B.; Hong, M. J. Mater. Chem. C 2017, 5, 1981-1989. doi:10.1039/c6tc05316e

71. Chuasaard, T.; Ngamjarurojana, A.; Surinwong, S.; Konno, T.; Bureekaew, S.; Rujiwatra, A. Inorg. Chem. 2018, 57, 2620-2630. doi:10.1021/acs.inorgchem.7b03016

72. Yang, Z.; Cao, J.; He, Y.; Yang, J. H.; Kim, T.; Peng, X.; Kim, J. S. Chem. Soc. Rev. 2014, 43, 4563-4601. doi:10.1039/c4cs00051j

73. Altomare, A.; Cascarano, G.; Giacovazzo, C.; Guagliardi, A.; Burla, M. C.; Polidori, G.; Camalli, M. J. Appl. Crystallogr. 1994, 27, 435. doi:10.1107/s002188989400021x

74. Sheldrick, G. M. Acta Crystallogr., Sect. A: Found. Crystallogr. 2008, 64, 112-122. doi:10.1107/s0108767307043930 
75. SHELXS-97, Program for Crystal Structure Solution; University of Göttingen: Göttingen, Germany, 1997.

76. Farrugia, L. J. J. Appl. Crystallogr. 1999, 32, 837-838.

doi:10.1107/s0021889899006020

77. Macrae, C. F.; Edgington, P. R.; McCabe, P.; Pidcock, E.;

Shields, G. P.; Taylor, R.; Towler, M.; van de Streek, J.

J. Appl. Crystallogr. 2006, 39, 453-457.

doi:10.1107/s002188980600731x

78. DIAMOND; Crystal Impact GbR: Bonn, Germany, 1999.

\section{License and Terms}

This is an Open Access article under the terms of the Creative Commons Attribution License

(http://creativecommons.org/licenses/by/4.0). Please note that the reuse, redistribution and reproduction in particular requires that the authors and source are credited.

The license is subject to the Beilstein Journal of

Nanotechnology terms and conditions:

(https://www.beilstein-journals.org/bjnano)

The definitive version of this article is the electronic one which can be found at:

doi:10.3762/bjnano.9.259 